ISSN 2073-4441

www.mdpi.com/journal/water

Article

\title{
Short Global History of Fountains
}

Petri S. Juuti ${ }^{1, *}$, Georgios P. Antoniou ${ }^{2}$, Walter Dragoni ${ }^{3}$, Fatma El-Gohary ${ }^{4}$, Giovanni De Feo ${ }^{5}$, Tapio S. Katko ${ }^{6}$, Riikka P. Rajala ${ }^{1}$, Xiao Yun Zheng ${ }^{7}$, Renato Drusiani ${ }^{8}$ and Andreas N. Angelakis ${ }^{9}$

1 International Environmental History Group, University of Tampere, Tampere FI-33014, Finland; E-Mail: riikka.rajala@uta.fi

2 Department of Architecture Engineering, NTUA, PhDc, Athens 10682, Greece;

E-Mail: antonioug@tee.gr

3 Department of Physics and Geology, Perugia University, Perugia 06123, Italy;

E-Mail: walter.dragoni@unipg.it

4 Water Pollution Research Department, National Research Center, Bohouth Str. Dokki, Cairo 12622, Egypt; E-Mail: fgohary@hotmail.com

5 Department of Industrial Engineering, University of Salerno, via Ponte don Melillo, Fisciano 1-84084, Italy; E-Mail: g.defeo@unisa.it

6 Capacity Development in Water and Environmental Services, Tampere University of Technology, Tampere FI-33720, Finland; E-Mail: tapio.katko@tut.fi

7 Yunnan Academy of Social Sciences, 577 Huan Cheng West Road, Kunming City 650034, China; E-Mail: zhengxy68@163.com

$8 \quad$ Federutility, Rome 00192, Italy; E-Mail: renato.drusiani@federutility.it

9 Institute of Iraklion, National Foundation for Agricultural Research (N.AG.RE.F.), Iraklion 71307, Greece; E-Mail: info@a-angelakis.gr

* Author to whom correspondence should be addressed; E-Mail: petri.juuti@uta.fi; Tel.: +358-50-3186-104.

Academic Editor: Enedir Ghisi

Received: 26 November 2014 / Accepted: 9 April 2015 / Published: 19 May 2015

Abstract: Water fountains are part of every human settlement, and historical and mythological stories. They are the source from which life-sustaining water was distributed to people until piped systems started providing fresh tap water inside buildings. In many places, people visit fountains to experience the freshness of running water, to prepare for prayers, or to make a wish. Fountains have also provided water for the people of cities under siege, and purified 
believers as part of holy rites. The Castalia shrine in Delphi, Greece, for its part, is a spot where various groups of people come to socialize, which greatly improves the quality of their lives. This paper is a look back through the history of fountains in various parts of the world. Experts from various areas have identified the historic, cultural, and ritualistic aspects of fountains and their findings are summarized. The paper concludes by providing a glimpse into the role of fountains in modern society and their continued influence in our lives today.

Keywords: Chinese civilizations; Egyptians; Etruscans; Minoans; Hellenes; Medieval times; Ottomans; Romans; water distribution; water supply systems

\title{
1. Prolegomena
}

\author{
Nullusenim fons non sacer. \\ (There is no spring which is not sacred), \\ Servius Marius Honoratus, \\ 4th century AD, Rome.
}

The English word "fountain" derives from the Latin word Fons, having the meaning both of natural spring and of artificial construction built for water supply and/or decorative or symbolic purposes. However, this paper sees fountains in a somewhat wider perspective that also covers artifacts such as water kiosks.

Fountains are known to have existed since the early Bronze Age in southeastern Greece and the Indus Valley. They were originally connected to springs or aqueducts to provide drinking water, water for bathing, and water for washing to the residents of palaces, cities, towns and villages. Advanced hydrotechnologies, including fountains, were first developed in Crete, the center of Europe's first advanced civilization, by the Minoans [1]. Later, they were improved and exported to other European and Mediterranean regions by Mycenaeans, Etruscans, Classical and Hellenistic Greeks, Romans, Venetians, and Ottomans [2].

Fountains were also used in several regions as decorations and to celebrate their builders besides being sources of drinking water. Hellenistic and Roman fountains were decorated with bronze or stone masks of animals or heroes. The baroque decorative fountains of Rome in the 17th and 18th centuries marked the arrival of restored Roman aqueducts glorifying the popes who built them [3]. By the end of the 19th century, indoor plumbing became a standard feature which is why many urban fountains - Earlier important as sources of drinking water around the world - Gradually began to be seen as monuments (built e.g., to decorate city parks and squares, honor cultural events and for recreation and entertainment). In addition, water transportation by gravity was replaced by pumping processes. The Jet d' eau in Lake Geneva, built in 1951, shoots water $140 \mathrm{~m}$ into the air. However, the highest fountain in the world is King Fahd's Fountain in Jeddah, Saudi Arabia, which spouts water $260 \mathrm{~m}$ above the Red Sea [4].

The evolution of the major achievements in the field of water fountains with emphasis on the major technologies throughout the centuries is presented and discussed in this study. Valuable insights into ancient water fountain technologies and management including their apparent durability characteristics, 
adaptability to the environment, and sustainability are also provided. A comparison of water technological developments in several civilizations is also made. These technologies are the underpinnings of the modern achievements in sanitary engineering, and the best proof that "the past is the key to the future". Furthermore, the timeline of the historical development of fountains worldwide over the last 5500 years of humankind's history is established and a chronological order is followed with emphasis on the major civilizations.

It is obvious that the existence of water fountains in a civilization had a lot to do with its location: whether its water supply sources were abundant, and whether they were above or below the level of the cities. The ancient Egyptians had ingenious systems for hoisting water from the Nile for drinking and irrigation. The Minoans, and later the Hellenes, led water down from mountains via aqueducts. Since the source was higher than the outlet, it was easy for the cities to build fountains that spouted or poured water into drinking water basins.

Rapid technological progress in the twentieth century created a disregard for past water technologies that were considered to be far behind the present ones. There were many unresolved problems relating to water distribution networks and, especially, fountains. In the developing world these problems became exacerbated to an unprecedented degree.

Moreover, new problems such as the contamination of surface and groundwater have arisen. Naturally, exacerbation of unresolved problems led societies to revisit the past and reinvestigate successful past achievements. To their surprise, the people that took part in the reinvestigation based on archaeological, historical, and technical evidence were impressed by two things: the similarity of past principles with the present ones and the advanced level of the lavatories engineering and urine separation practices of earlier periods [5].

Our hope is that these small case studies covering various time periods and different parts of the world describe adequately the diversity of water fountains over time.

\section{Minoans and Ancient Egyptians}

\subsection{Water Distribution Systems}

Several different types of conduits have been found during archaeological excavations in Minoan Crete, Greece. They were used for water supply as well as removal of storm water and wastewater. Therefore, they are made mainly of stone or terracotta. The terracotta conduits were canals or pipes of rectangular or circular cross-section. The most interesting conduits are the U-shaped and truncated conical terracotta pipes never used before by other civilizations [6]. In the Knossos Palace, water distribution was through a network of terracotta piping located beneath the floors at depths from a few centimeters to $3 \mathrm{~m} \mathrm{[7].}$ Minoan terracotta pipes were used for both distribution and collection of water for storage. Consequently, the terracotta pipe had to be designed to perform [8]:

(a) Underground Transportation of Water: This (underground = unseen) system may have been intended for use by a restricted group of people or for a specific activity, which in turn may be indicative of ritual use of water [9]. 
(b) Transportation of Good Quality Water. The evidence also suggests that the pipes probably fed fountains in open areas of the palaces which were not part of the domestic distribution system, according to several scholars [10].

\subsection{Fountains}

Despite their aesthetic accomplishments in palatial frescoes and architecture, fine artifacts of pottery, metals, precious and semi-precious stones, the Minoans had to grapple with practical problems related to water and wastewater. Thus, the extensive and elaborate structures they built for water supply included fountains planned and constructed to serve the needs of the growing population of the island.

A remarkable fragment from a fresco composition depicting a fountain of a supposedly Minoan garden was found in the House of Frescoes in Knossos [9]. The fragment has been restored to what appears to have been a jet d'eau fountain. Although the actual top of the fresco was not found, the object depicted in the upper part of the field is clearly some type of fountain or jet d'eau where the water spout rises from a forked base. Minoan fountains manifest another interesting technology [11]. Most of them are subterranean structures supplied with water directly or from other springs via ducts.

The most typical of these fountains is the Tykte fountain, which was discovered in the Guest House (Caravanserai) of Knossos (Figure 1a). It is located in the restored "Room of Spring" or "Minoan Fountain". It is a rectangular underground structure with a central cistern-basin (of three steps measuring $2.0 \times 1.6 \mathrm{~m}$ ), which was accessible from the courtyard of the adjacent building with three descending stairs at the end of which on the right was a circular slotted door [7]. The walls of the "Room of the Fountain" were constructed of large limestone blocks and slabs of internally coated gypsum $[2,12]$.

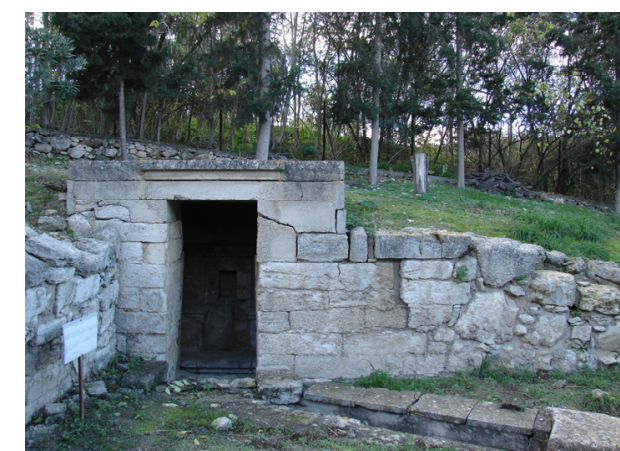

(a)

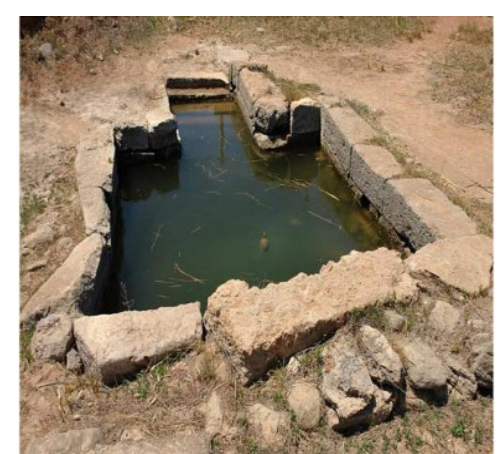

(b)

Figure 1. Tykte fountains: (a) at Caravanserai in Knossos palace and (b) at Zakros palace (photo by Andreas N. Angelakis).

The water depth in the cistern could reach $45 \mathrm{~cm}$. The water did not reach that level through a channel, but was supplied by an artesian spring naturally through the pebbles forming the bottom. The plate at the entrance was very worn, perhaps from filling of the vessel with water. The Minoan Fountain was a very sophisticated construction. The conch and double crown square section on the wall opposite the entrance was probably designed to contain a lamp.

Another similar Tykte fountain is that of the Zakro palace (Figure 1b). It is located in the southwest corner of the Hall of the Cistern and has an opening which leads to a small chamber where water was collected and channelled under the floor into a square underground fountain [8,11]. Its dimensions are 
$3 \times 4 \mathrm{~m}$ and it dates to the Neopalatial period ( $c a$. 1700-1500 BC). For more details, see [8]. Two hand-made tubes about $30 \mathrm{~cm}$ long with a narrow opening on the zoomorphic side were found in a building (Figure 2). These artifacts also date back to the Neopalatial period. Floods [13] indicated that the Mediterranean dry-season became more pronounced on Crete during the Late Minoan IB (ca. 1500-1450 BC).
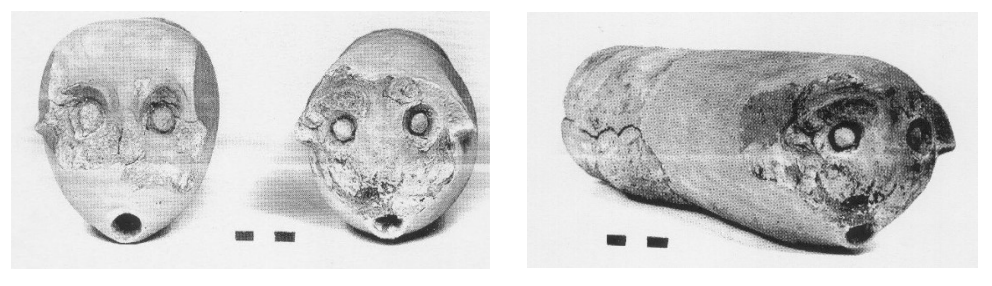

Figure 2. Zoomorphic type waterspouts.

It was perhaps a particularly dry period with more pronounced summer temperatures or less winter precipitation. This position is supported by the increase in the scale of Minoan water-management activities then, especially in the eastern regions of the island. It appears that Minoan Crete responded to the changing climatic conditions sometime during the Middle Bronze Age. At that time, the management of water resources became increasingly important [14]. Technologies such as gutters, wells, dams, ceramic mulches to conserve soil moisture, terraced hillsides, and Tykte fountains were widely used.

Minoans, as the later Greek civilizations, avoided regions of fertile soils and high water availability. They usually resided in areas under water scarcity. Thus, it is likely that lack of water triggered progress, particularly in water sciences, among people living in dry are as during the Minoan Era.

\subsection{Non-European Ancient Civilizations (from 3000 Onwards)}

During the early phases, fountains were used especially for public water supply purposes. The very first evidence of a water supply network emerged when cities of the first ancient civilizations (Egypt, Sumerian and other civilizations in the Middle East, Indus River, and China) were studied. Ancient civilizations of the New World (e.g., Maya, Aztec, and Inca) also developed sophisticated water systems, fountains being an important part of them. According to Hirst [15], the first still remaining fountains originated in ca. $3000 \mathrm{BC}$ :

"The earliest surviving carved water basin, dating from around $3000 \mathrm{BC}$, was discovered at the site of Tello, one of the cities of Mesopotamia. At Mari, another of the most important cities, a stone fountain figure dating from around 2000 BC was discovered. The figure can be considered a prototype for the kind of fountains made in gardens for thousands of years thereafter: a female goddess holding a base into which water is piped to cascade forth, symbolizing the source of all life, the ultimate creative force of the garden" [15].

\section{Etruscan Civilization (ca. 800 BC-200 AD)}

Before delving in to the Roman attitude towards water management, aqueducts and fountains in more detail, we must remind ourselves that since ancient times, Roman hydraulic technology was known to have its roots in the Etruscan civilization. The Etruscan civilization, whose development was influenced 
by Greece and the Near East, flourished in central Italy from about the eight century BC onwards. Etruscans were masters of land reclamation, aqueduct building and water management in general, cf. e.g., [16-18]. The tunnel shown in Figure 3, which still works, was built in order to control the discharge of a small catchment close to the ancient Etruscan city of Veii, a few kilometers from Rome.

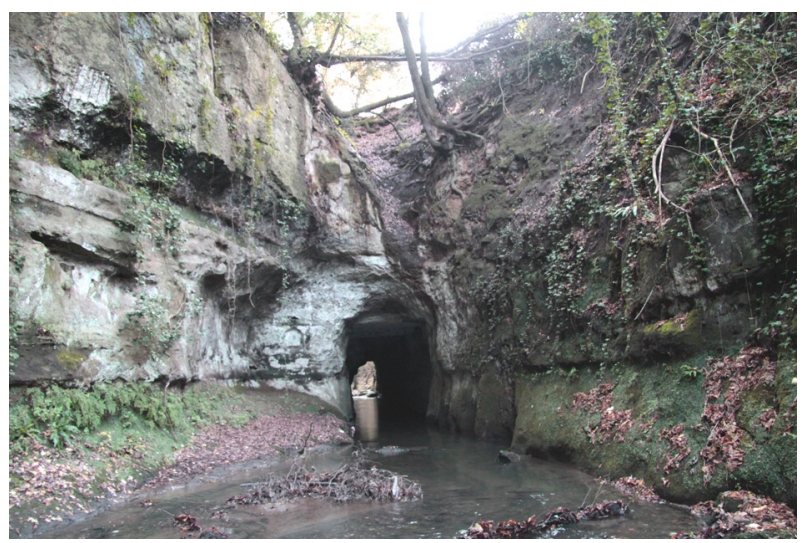

Figure 3. The Etruscan Ponte Sodo, a tunnel about $75 \mathrm{~m}$ long. It is a good example of the Etruscan hydraulic technology; its main purpose appears to have been to control floods and reclaim land close to Veii, the Etruscan city located a few kilometers from Rome (photo by Walter Dragoni).

During its early history, Rome was ruled by Etruscan kings, the last of which was over thrown around the end of 6th century BC. The Etruscan kings transformed Rome into a true city, reclaiming swampy land between the hills and building the first sewers, of which the Cloaca Maxima (Greatest Sewer) is the best known. Etruscan rule and the peaceful and bellicose relations between the two ethnic groups left the Romans a patrimony of cultural and religious attitudes and rituals, as well as a sound knowledge of hydraulic technology. By the first century BC, after a few centuries of turbulent relationships and wars, the Etruscans were absorbed by Rome ( $c f$. e.g., [19]). After the conquest and the following initial destruction, most Etruscan cities and settlements continued to exist as Roman centers. Hence, over the centuries, most old Etruscan buildings and public structures were substituted by Roman ones. This explains why, at present, no remains of entire Etruscan fountains in good condition exist. Remains of basins and pertinent hydraulic structures and conduits, however, are plentiful, but are mainly part of temples and sanctuaries [20], as in the case of the Etruscan town of Marzabotto, in Northern Italy (Figure 4). The fountain fed by an aqueduct destroyed during excavations has been dated to between $c a$. 500 and $350 \mathrm{BC}$. These dates are believed to be the (approximate) dates of the foundation and destruction of the Etruscan city by the Gallic tribes.

In spite of the scarcity of remains of Etruscan fountains, some interesting information has been derived from paintings and ceramics. For instance, in the mural painting of a fountain (Tomb of the Bulls, Tarquinia, and Southern Etruria) shown in Figure 5, water flows out of the mouth of two animals, whose positions suggest the presence of pressure pipes. The Etruscans appreciated highly Greek pottery and ceramics. Therefore, Greek cups and vases are often found in Etruscan tombs. In many cases, the ceramics were decorated with scenes where the focus was on one or more fountains. A splendid Hellenic hydria, found in an Etruscan tomb of Vulci, in Southern Etruria is shown in Figure 6. Figure 7 reproduces the scene of another vase, in which a few young women are fetching water from a fountain [21]. It is 
noteworthy that the drawing in Figure 7 represents a scene which is still common today in many developing countries. Actually, some of the older authors of this paper also remember having seen similar scenes since many Mediterranean villages had no piped water in houses until the second half of the 20th century, and had to rely on a free flowing public fountain. The water jar was also often carried on the head as shown in Figure 7.

There is no doubt that Etruscans had actual fountains similar to those represented on their cups and vessels. An actual faucet of an Etruscan fountain in the shape of a lion's head, quite similar to that of Figures 7 and 8, is shown in Figure 9. It was found in Orvieto at the San Giovenale site and probably dates back to around the end of the 6th century BC [20].

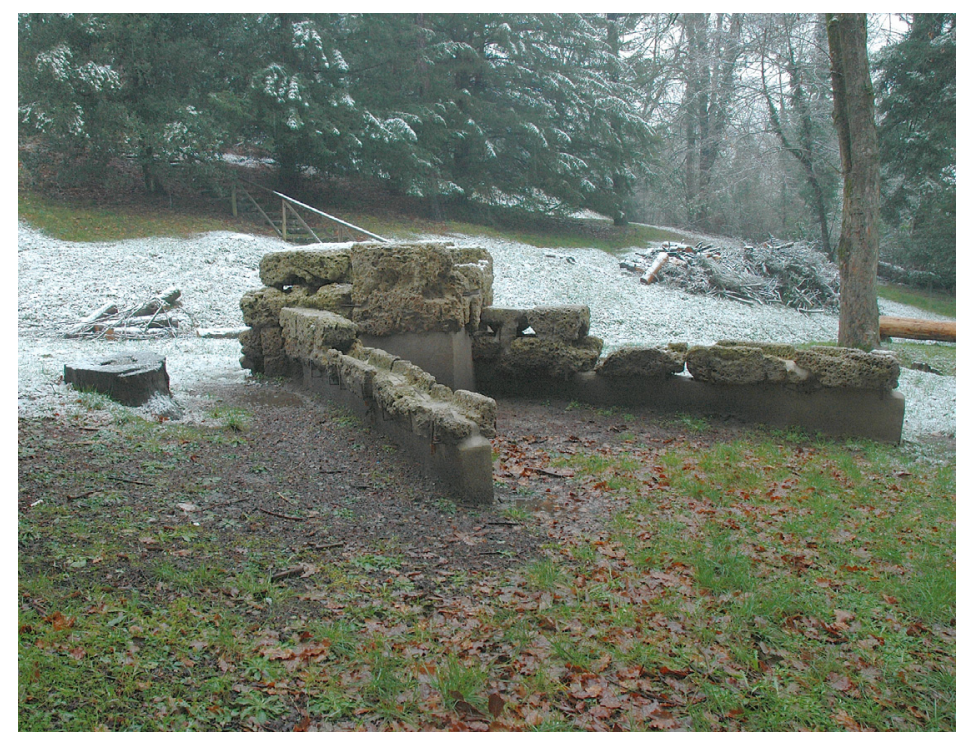

Figure 4. Etruscan Fountain of Marzabotto, northern Italy, ca. 500-350 BC (photo by Walter Dragoni).

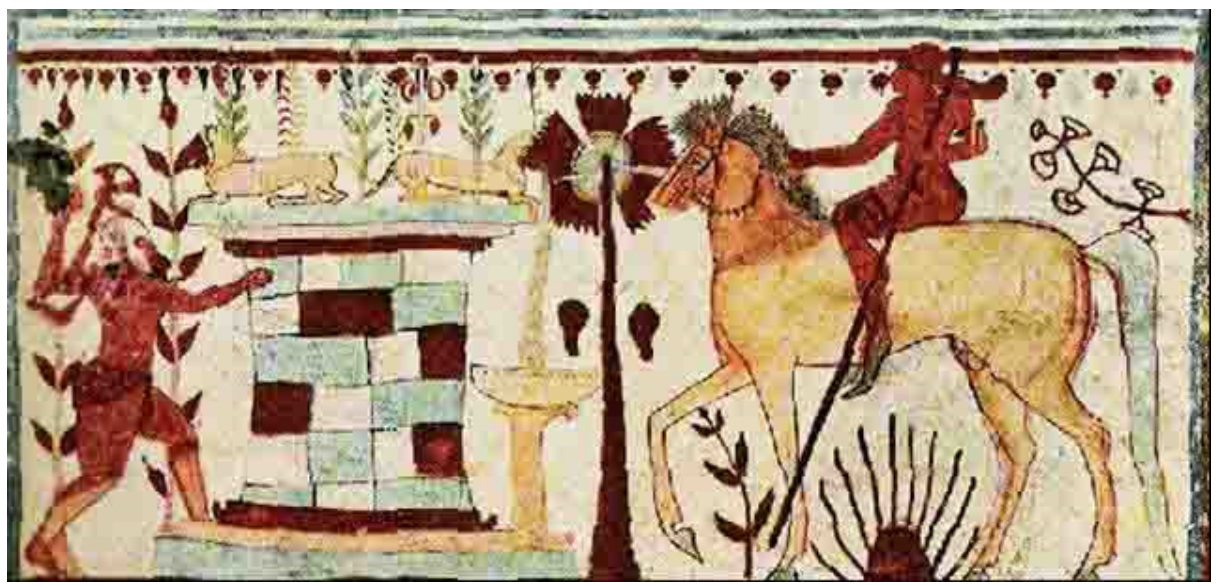

Figure 5. A painting in the "Tomba dei tori" (Tomb of bulls), in Tarquinia, Southern Etruria (ca. 540-530 BC). The painting probably depicts a scene of Greek mythology [22]. 


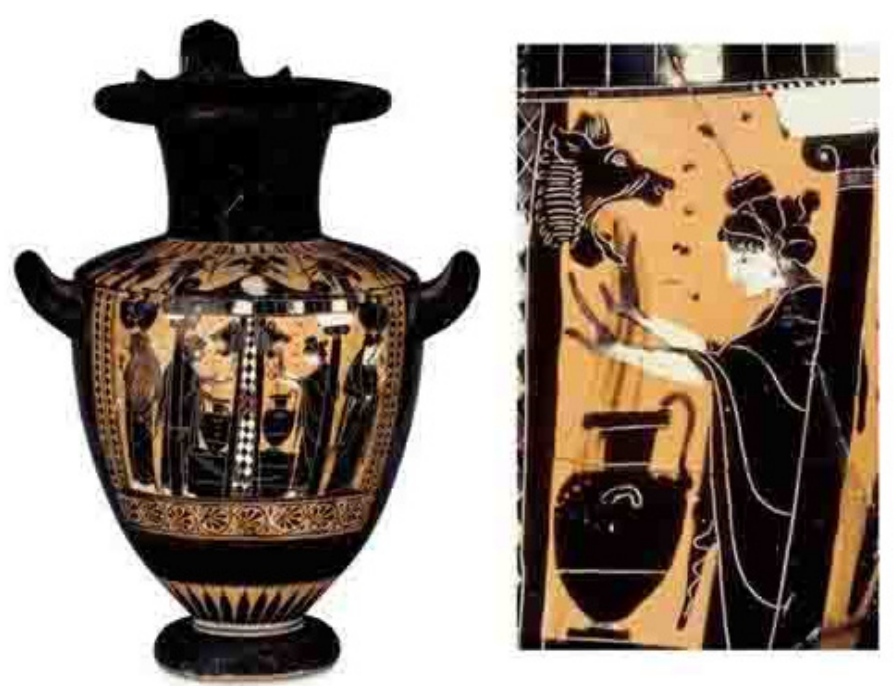

Figure 6. Attic vase found in an Etruscan tomb in Vulci, Southern Etruria (Trustees of the British Museum).

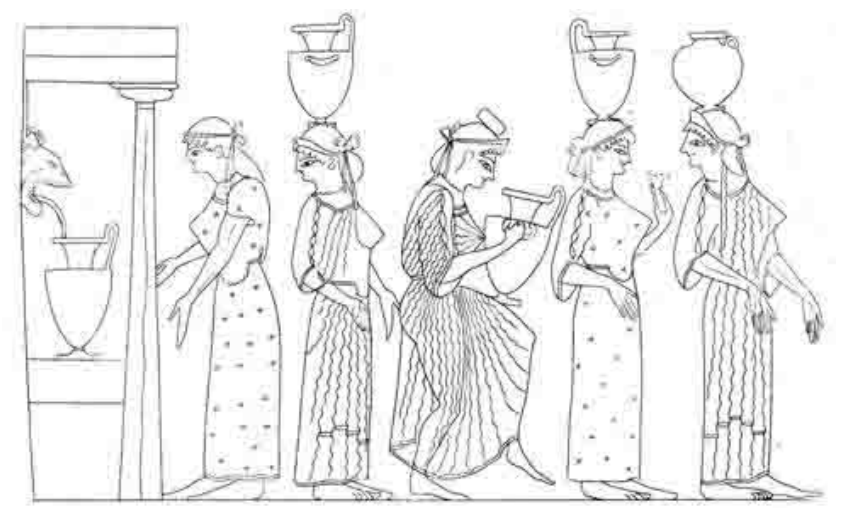

Figure 7. Women fetching water from a fountain. Painting reproduced from an engraving in an vase found in an Etruscan tomb [21].

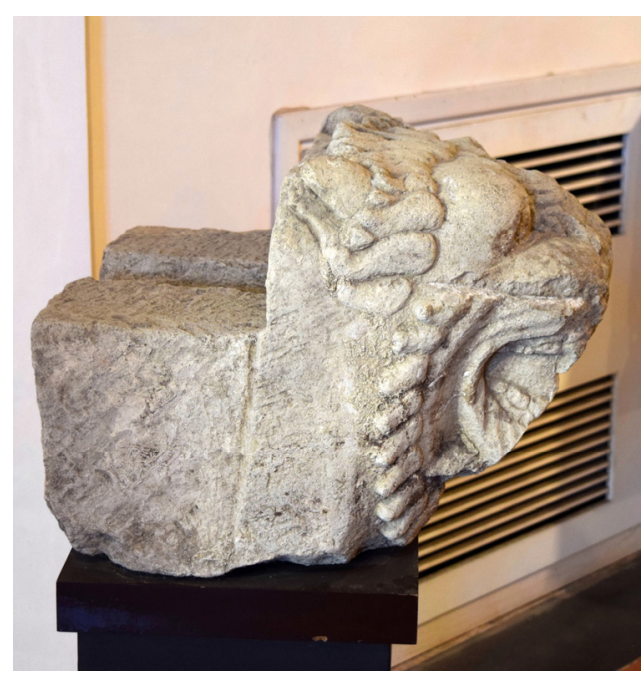

Figure 8. Faucet of an Etruscan fountain found in San Giovenale (Orvieto), reproduced with kind permission of the Museum "Claudio Faina", Orvieto, Italy (photo by Walter Dragoni). 


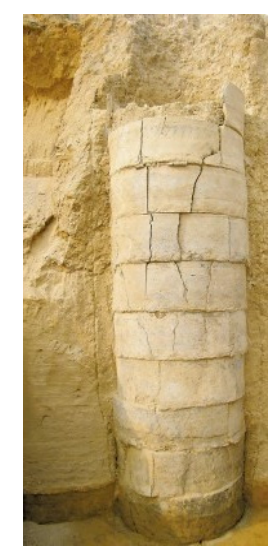

Figure 9. Earthenware well of Early Han Dynasty.

\section{The History of Wells and Fountains in Early Chinese Dynasties}

In China, water was first distributed to houses through taps in the late 19th century in some major cities. The Chinese generally obtain water for daily use from two sources: dug wells and nearby streams. Wells are the main water supply structure in China and have played a very important role until today throughout the country. In many places, people also use water from springs, which they lead via ditches into residential areas, where they build special structures with a spiritual meaning over the supply point.

Based on evidence from the earliest ruins of a well discovered in $\mathrm{He} \mathrm{Mu} \mathrm{Du}$ in Zhejiang Province in 1974, the history of the well in China dates back about 6000 years. The ruins were those of a well of wooden construction [23]. Later, many other old well sites used in ancient China around that time were discovered. The early civilization of China emerged initially in the mid-basins of the Yellow River and the Yangtze River. The wells dug there allowed settlements to be spread beyond the river banks.

The structure of the well developed over the years. Archaeological findings show that the early wells (around 3000 BC) were built of wood and were usually square. In the Fighting-States period (475-221 BC), the well wall was built of earthenware because it was a popular material then. An earthenware well of the Early Han Dynasty discovered in Yeng County is shown in Figure 9. About 40 wells were discovered in the same ruins each approximately 5 to $7 \mathrm{~m}$ deep with a diameter of $1.3 \mathrm{~m}$ [24].

During the Han Dynasty (ca. 202 BC-220 AD) and subsequent dynasties, wells were commonly built of bricks. That made them firmer and more diversified [25]. However, since around the Tang Dynasty (618-907 AD), the covered structure started gaining popularity in residential areas (compared to wells for irrigational purposes in farming communities). Therefore, people preferred to build a stone structure above their well to make it more firm and beautiful and to serve as a spiritual symbol. A typical such structure (Song Dynasty, ca. 960-1279 AD) is shown in Figure 10.

The Dai are an ethnic group in China living mainly in Yunnan. Their villages usually have one or two public wells. The villagers always build a special structure above the well, such as a Buddhist tower, a temple-style house, and a dragon head to beautify it. It makes the well a special place, even holy. Today, tap water is commonly used in these areas, but most villages still following the tradition of using well water for drinking and cooking (Figure 11) ([5], p. 43). 


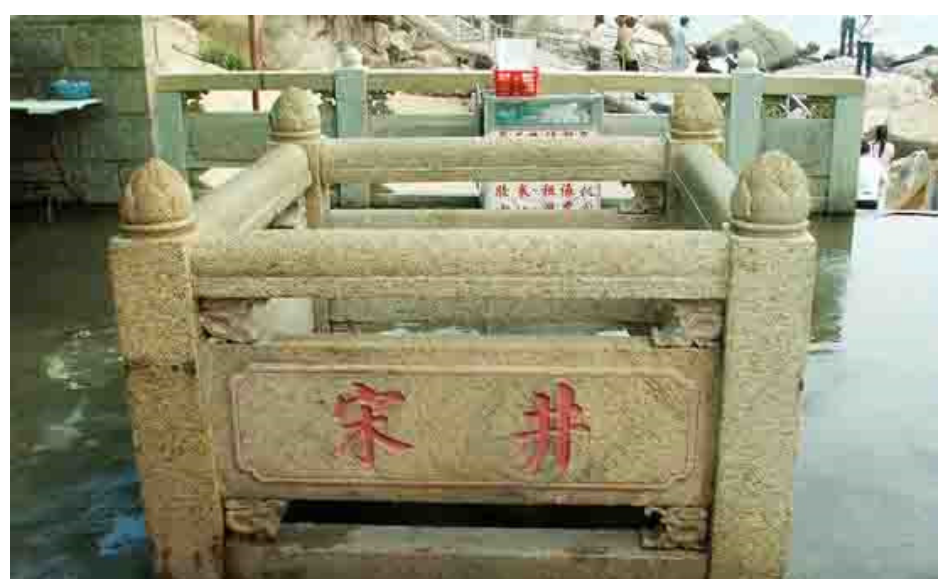

Figure 10. Well structure in Chaozhou City built during the Song Dynasty.

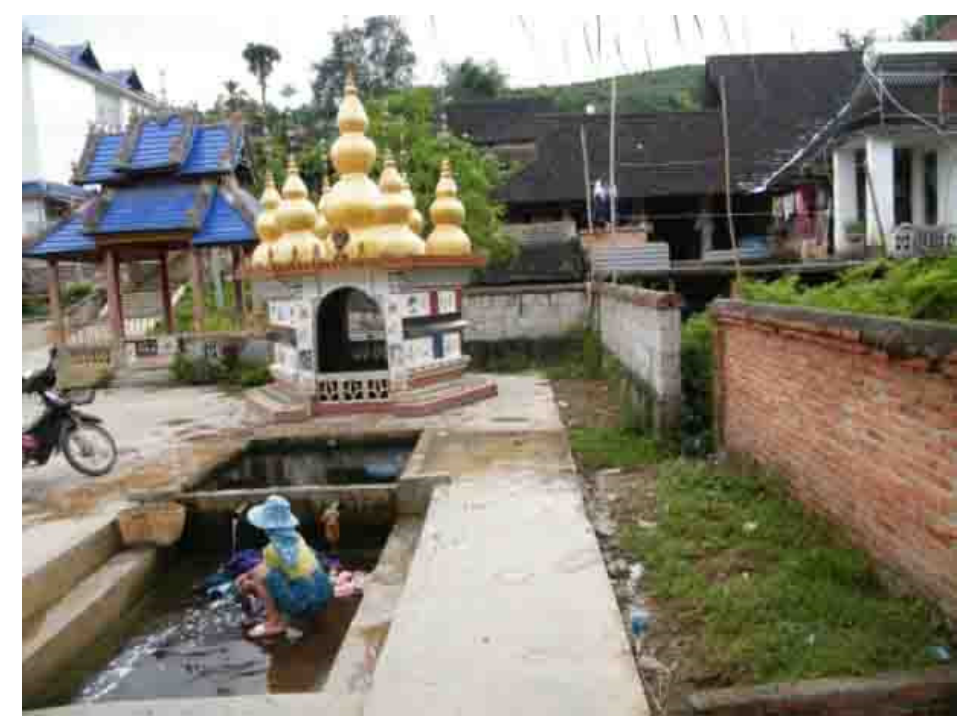

Figure 11. The well of a Dai Village.

\section{Greco-Roman European Classical Antiquity}

\subsection{The Classical and Hellenistic periods (ca.5thc.-1stc. BC)}

In ancient Greek cities, shrines and fountains were mainly linked to social and public life in the Agoras and religious beliefs about gods and nymphs living by water. Fountains existed in every ancient Greek city such as Athens, Corinth, and Megara, and in every sanctuary such as Delphi and Epidauros. Some of them supplied water from springs and rivers into the cities since the $c a$. 6th century BC as terminal points of aqueducts.

Greek fountains were made of limestone or marble. Often the water flowing through lead pipes emerged from the mouth of a sculpted mask representing the head of a lion or the muzzle of some other animal. Most Greek fountains flowed by simple gravity, but water pressure and the siphoning principle were also used to make water jet or spout out (as seen on Greek vases). Many images and illustrations of the uses and other aspects of ancient Greek fountains have survived on the vases of that period (Figure 12). 


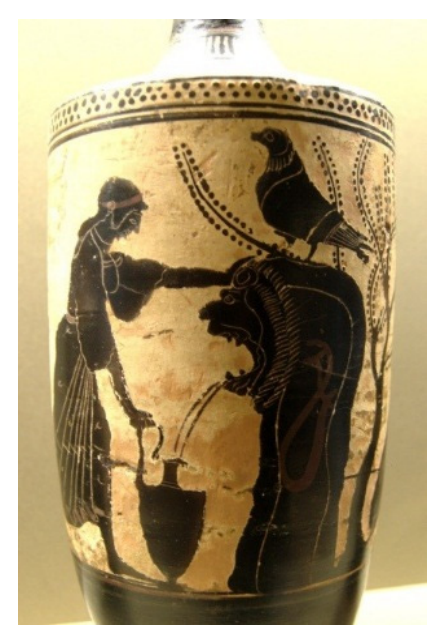

Figure 12. Attic Greek vases: from South Italy, about $480 \mathrm{BC}$ showing Polyxena filling a vessel from a fountain (The Louvre) [26].

The fountains were discovered either in central areas of settlements or the Agoras of Classical and Hellenistic cities, or in sanctuaries or sacred places. In the last mentioned, they were not only for water supply, but also for ritual purposes.

The typical ancient Greek water supply fountain (see Figure 13) consisted of a single- or rarely a double-basin small tank, as in the case of the Enneakrounos fountain, from where water either overflowed through simple stone or ornamented spouts, or was carried out in clay jars and vessels or leather utricles. However, such a tank was in many cases at the front of a larger water reservoir, as in the fountains of "Theagenes" at Megara in Attiki (Figure 14), which was filled by water either from a spring or from an underground water harvesting tunnel network. In very few cases they were supplied with rainwater.
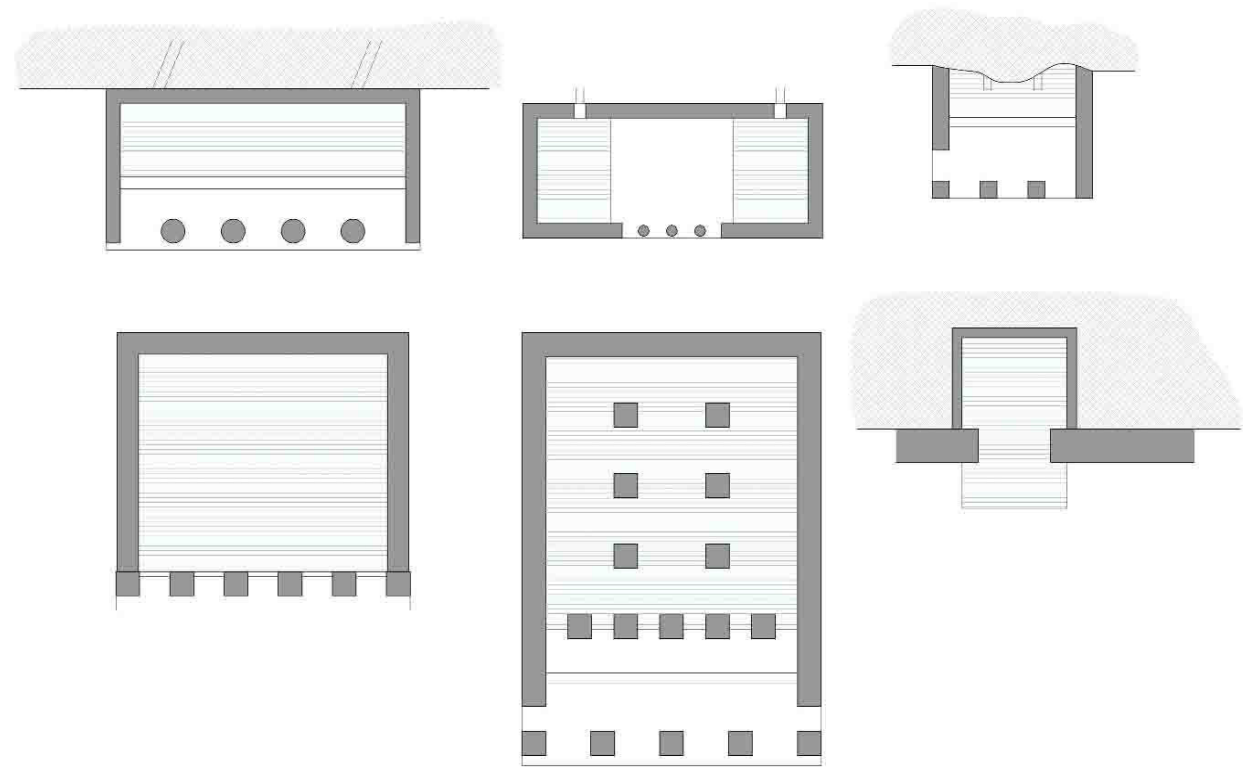

Figure 13. Most common types of ancient Greek fountains by cross-sections, (photo by Georgios P. Antoniou). 


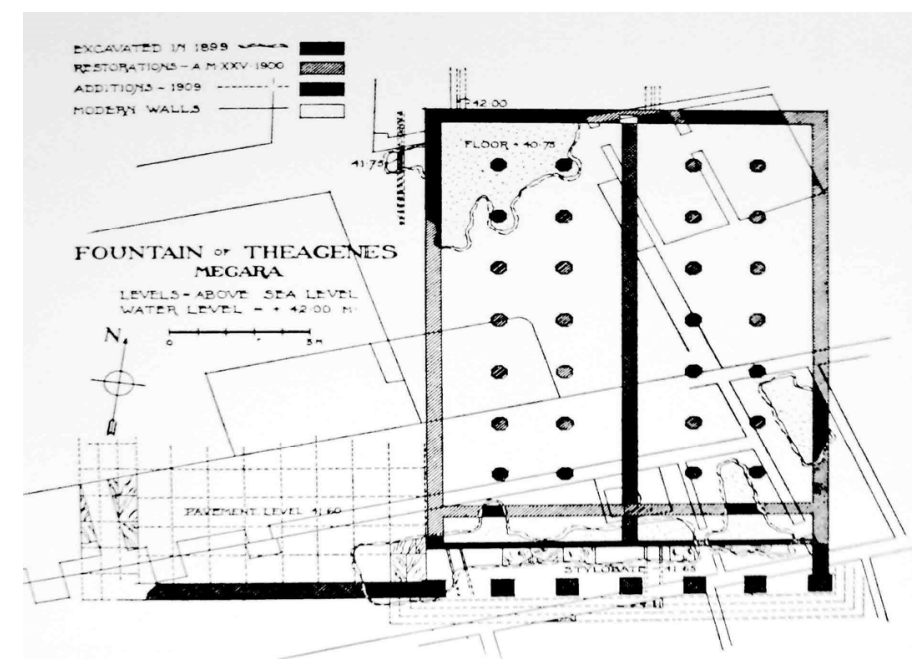

Figure 14. The fountain of "Theagenes" at Megara [27].

Many of the archetypal Classical and Hellenistic fountains were constructed either in a retaining wall such as the Palestra of Sikion and the Asklepeion of Kos, or in the rear wall of a portico such as the south stoa of the Athenian Agora. Quite often, the fountains were attached to the natural rock from which the water was harvested, as in Ialyssos or Corinth where the fountains had been hewn out of the soft local rock. Architecturally, a colonnade or portico usually formed the façade of the fountains (Figure 15). It was usually narrow as at Megara and Ialyssos on Rhodes.

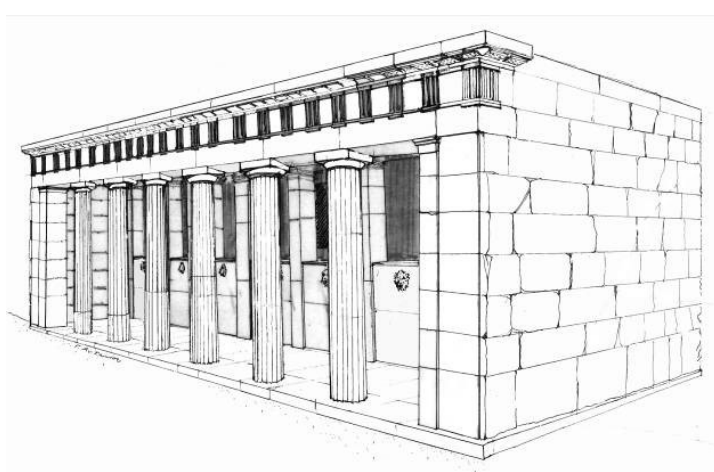

(a)

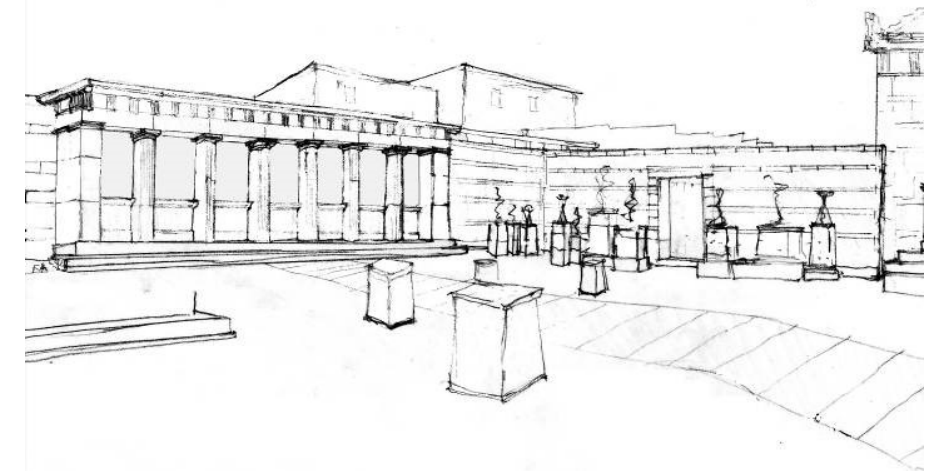

(b)

Figure 15. Fountains: (a) The Doric Fountain at Ialyssos, Rhodes (reconstruction by Georgios P. Antoniou) and (b) The Fountain at the Agora of Kameiros, Rhodes (reconstruction by Georgios P. Antoniou).

The other category of ancient Greek fountains consisted of religious ones or those for ritual purposes, as mentioned earlier. Most of them were attached to sanctuaries or sacred places. The Castalia fountain was one of them, but public. Many of the ritual fountains were grottos, dug completely or partially in rock. Their structure served the needs of the sanctuary. As mentioned briefly before, there were a few different methods for water acquisition. The simplest one was to use spring water. For instance, the sacred spring Castalia in Delphi was supplied by the springs of Maleata's hill and the fountains at the Asklepeion of Kos. Rainwater cisterns and water conveyed by regular aqueducts were not commonly used (Figures 16 and 17). 


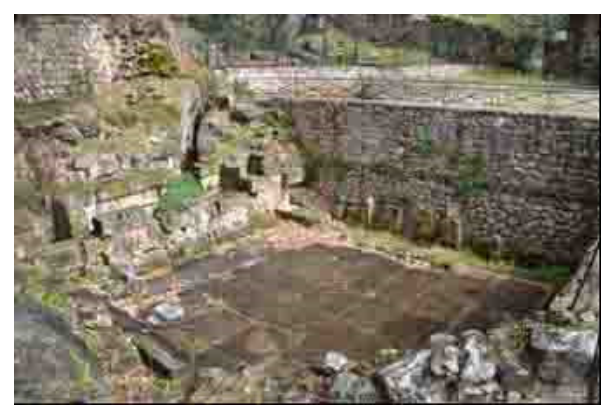

(a)

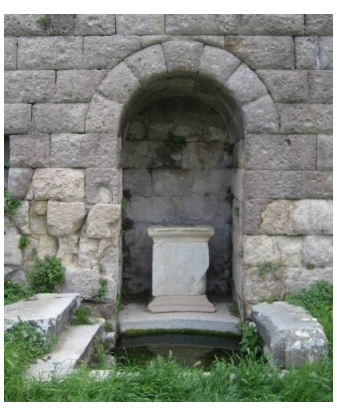

(b)

Figure 16. (a) The archaic spring in Delphi; a type of branch of the famous Castalia spring (with permission of Andreas N. Angelakis) and (b) Asklepeion Kos; one of the fountains flanking the monumental stairway.

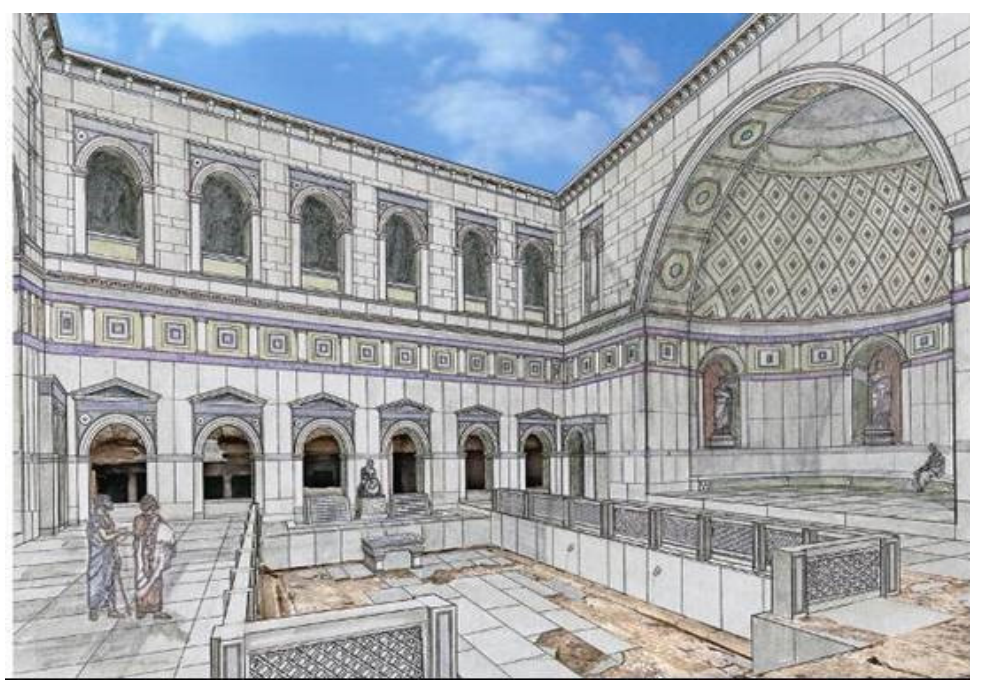

Figure 17. Peirene fountain in ancient Corinth, Greece (construction phase during the Roman Herodes Atticus) (Georgios P. Antoniou).

In contrast, underground water harvesting conduits were the most common method applied since the time of the Peisistratos aqueduct in Athens dating back to the $c a$. 6th century BC. That water supply network collected not only spring water, but also groundwater from the foot of Mt Hymytus, at almost the same time as the well-known qanats [28]. Most of the famous fountains of the Athenian Agora like Enneakrounos were supplied by the aqueduct which is still conveying water to the National Gardens in Athens.

The Doric fountain at Ialyssos, Rhodes was also supplied by an extensive network of water harvesting conduits hewn in the rock to which the fountain was attached. In Corinth, not only the two main fountains of the Agora, Peirene and Sacred, were supplied by an extensive network of water harvesting conduits, but also the Glauke and Lerna, westwards and northwards, respectively. Moreover, the technique not only supplied the fountains attached to a rocky backfill, but also the free standing buildings such as the Fountain of "Theagenes" [29] which received water from similar underground tunnels.

Several small-scale functional constructions facilitated water extraction. They were intended either for filling buckets or flasks or most commonly ceramic jars (hydria). Drainage and other pipes, on the other hand, ensured the removal of surplus water. There were also generally methods and structures that allowed 
directing a reasonable amount of the water for reuse in lavatories or elsewhere [30]. Moreover, numerous small structures such as intake openings [29], Y-shaped clay pipes [31] and even the tar waterproofing of the "Theagenes" Fountain at Megara [29] are proof of the innovative techniques and construction know-how of the engineers and architects of that era also in this field.

The two well-known springs of antiquity in the Corinthian Agora, Peirene (Figure 17) and the Sacred Spring, were supplied with water by a network of underground water harvesting channels running southwest and partially to the southeast. Another famous spring and fountain of antiquity is the Castalian Spring in the ravine between the Phaedriades at Delphi. It was — and still is — situated at the place where all visitors to Delphi, who came to consult the Delphic Oracle, stopped to purify themselves before meeting the Oracle. At that same spot Apollo killed the monster (Python) according to mythology. Two fountains fed by the spring still exist [32].

\subsection{Roman Period (4th c. BC-4th c. AD)}

Rome, which according to tradition was founded in $753 \mathrm{BC}$, inherited and advanced greatly the hydraulic knowledge of the Etruscans. Their technology remained unsurpassed till the end of the 18th century. Since Roman hydraulic technology was closely linked to the Etruscan one for the first centuries after the foundation of Rome, only the period after the construction of the first aqueduct (in $312 \mathrm{BC}$ ) will be considered. According to Sextus Julius Frontinus [33,34], the Roman consul who was named curator aquarum (guardian of the water) of Rome in $98 \mathrm{AD}$, Rome had nine aqueducts. Two hundred years later there were eleven, as two more were built in 109 and 226 AD [34]. The aqueducts of Rome, plus a few small local springs, supplied water to hundreds of public fountains and a few dozen monumental fountains and large private and public thermal baths, not counting the water supplied to the Imperial household and owners of private villas. Even in the fourth century, in a deep decline, Rome had 1352 fountains or cisterns [35]. The quantity of water and number of fountains in Rome was so large that the term Roma regina aquarum (Rome queen of the waters) has been commonly used since antiquity. The attitude of ancient Rome towards water and fountains left a permanent imprint on Rome (and Italy), which survived the fall of the Roman Empire and probably still exists. Rome is the city with the highest number of monumental and artistic fountains. Today, there are also more than one thousand little fountains along the streets of Rome providing excellent free drinking water to everybody.

"Roman fountains" are such a broad subject that only a few pieces of general information and little known examples can be given here about them. The interested reader can easily find more information on the Internet; for recent printed publications see e.g., [16,35,36].

The Roman Empire extended from the Spanish Atlantic coast to the Rhine River in Germany and the Black Sea, and from the Scottish Lowlands to a few hundred kilometers south of the North African Mediterranean coast [37]. In that large Empire, all Roman cities of any importance had a Forum (the business area), a theatre, an amphitheater, a military barracks, public baths and the necessary aqueducts and fountains to provide water for these structures.

Roman pipes were made of wood, stone, mortar, terracotta and lead; the taps and valves were of high-quality bronze alloys, similar to modern ones. A good example of Roman water supply planning is Pompeii, the city destroyed by the Vesuvius eruption in 79 AD. Pompeii's water was supplied by an aqueduct. So far, over forty of the city's public fountains have been discovered, and it appears that most 
houses were no more than $50 \mathrm{~m}$ from a public fountain. The fountains were supplied by lead pipes under pressure $[38,39]$. The simplest form of street fountain in Pompeii was generally equipped with an oblong stone basin, typically about $1.5 \times 1.8 \mathrm{~m}^{2}$ and $0.8 \mathrm{~m}$ high, into which a spout discharged, and the basin was presumably normally full. The fountains were deliberately designed to overflow in order to clean the streets [16,40-42]. Excellent pictures of Pompeii fountains can be seen in [43].

Fountains were common in the private houses of wealthy families. In Roman cities and private villas, fountains with water jets where not rare. For example, in Pompeii, the House of the Bracelet had a spectacular mosaic fountain with 29 water jets in its triclinium ([44], as reported in [38]). Pliny the Younger describes his villas as having gardens and fountains with jets [45]. The Villa of Emperor Hadrian in Tivoli (Figure 18), had immense large fountains and basins, and fountains with jets [46].

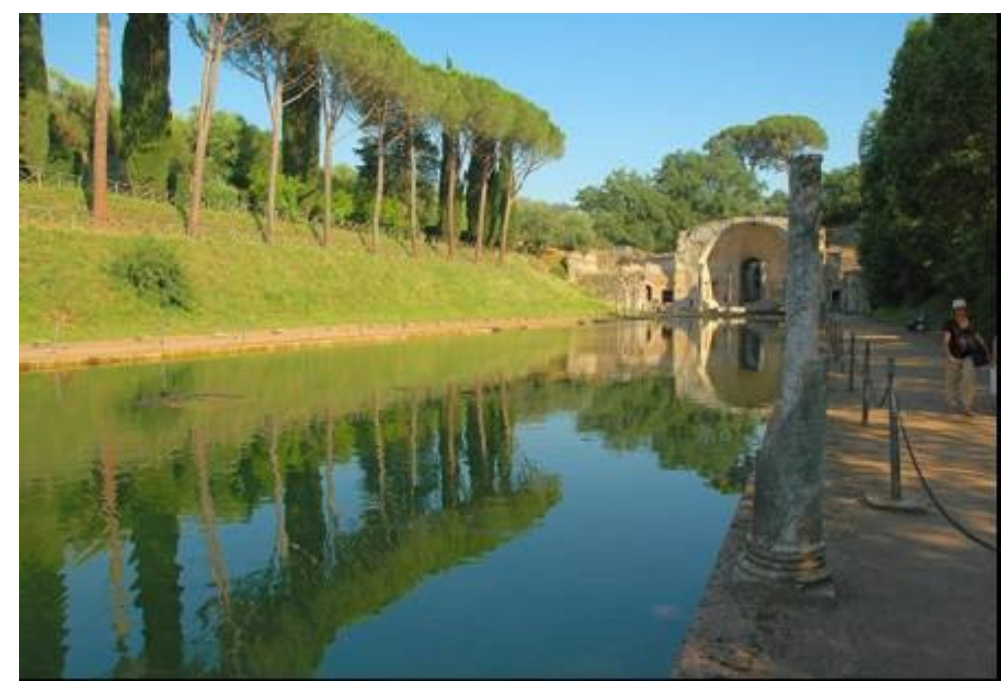

Figure 18. One of the fountains in the Villa of Emperor Adrian (76-138 AD) in Tivoli, close to Rome (photo by Walter Dragoni).

Not far from the city of Pompeii, in the District of Salerno, there is a Roman tunnel in the rock in the village of Sant'Egidio del Monte Albino in the Sarno River basin. The tunnel was constructed in order to supply a public fountain which stands on the grounds of an ancient Roman villa (Villa Helvius). The little known Helvius fountain is quite different from the public fountains in nearby Pompeii. The Helvius fountain was not constructed of matched slabs of limestone or Vesuvian stone. It was built from a single block of white marble. In addition, as shown in Figure 19, it has sculptural decorations on the three exposed sides representing the River Sarno along its path from the spring toward the sea [40,42].

In Roman cities, all buildings planned for frequentation by a large number of people, like theatres and amphitheaters, had many fountains for public service. Hence, they were built according to a rational plan. A good example is the Coliseum in Rome, completed in $80 \mathrm{AD}$, which could accommodate up to 65,000 spectators for games that could last a few days. That required a sophisticated hydraulic system for latrines and fountains. In addition, indeed, traces of 92 fountains are visible today [47]; those of one are shown in Figure 20. 


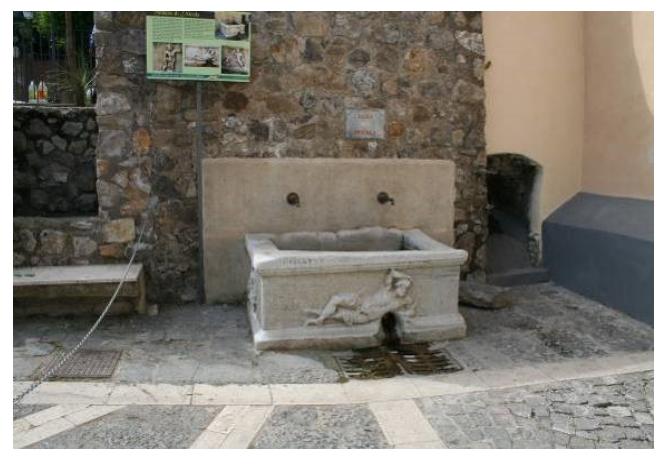

(a)

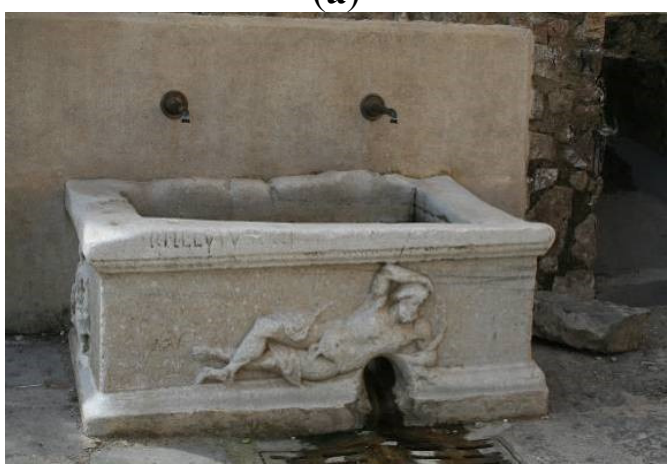

(c)

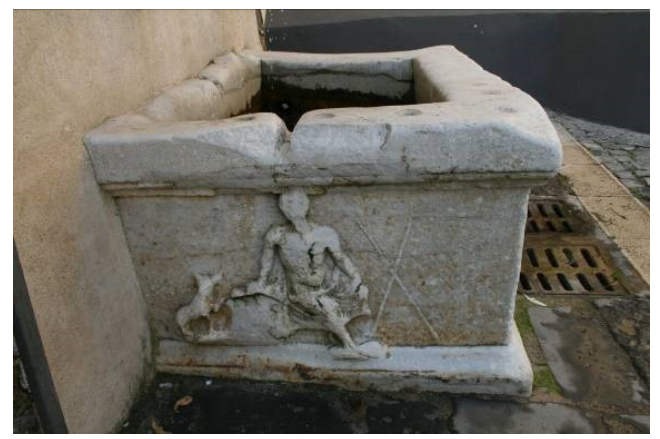

(b)

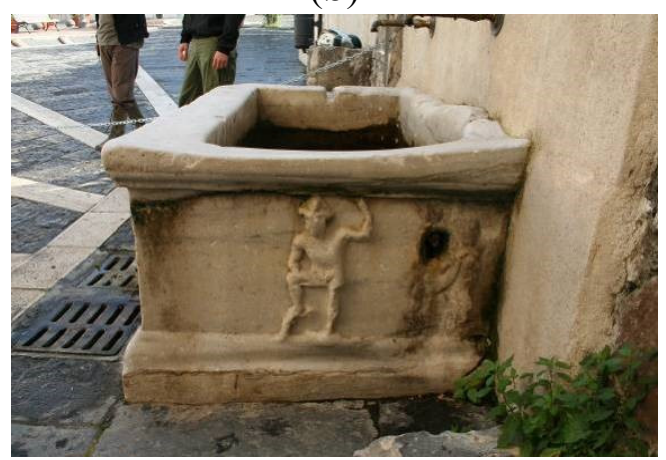

(d)

Figure 19. Helvius fountain in the village of Sant' Egidiodel Monte Albino in the Sarno Valley: (a) global view; (b) left view; (c) front view; and (d) right view.
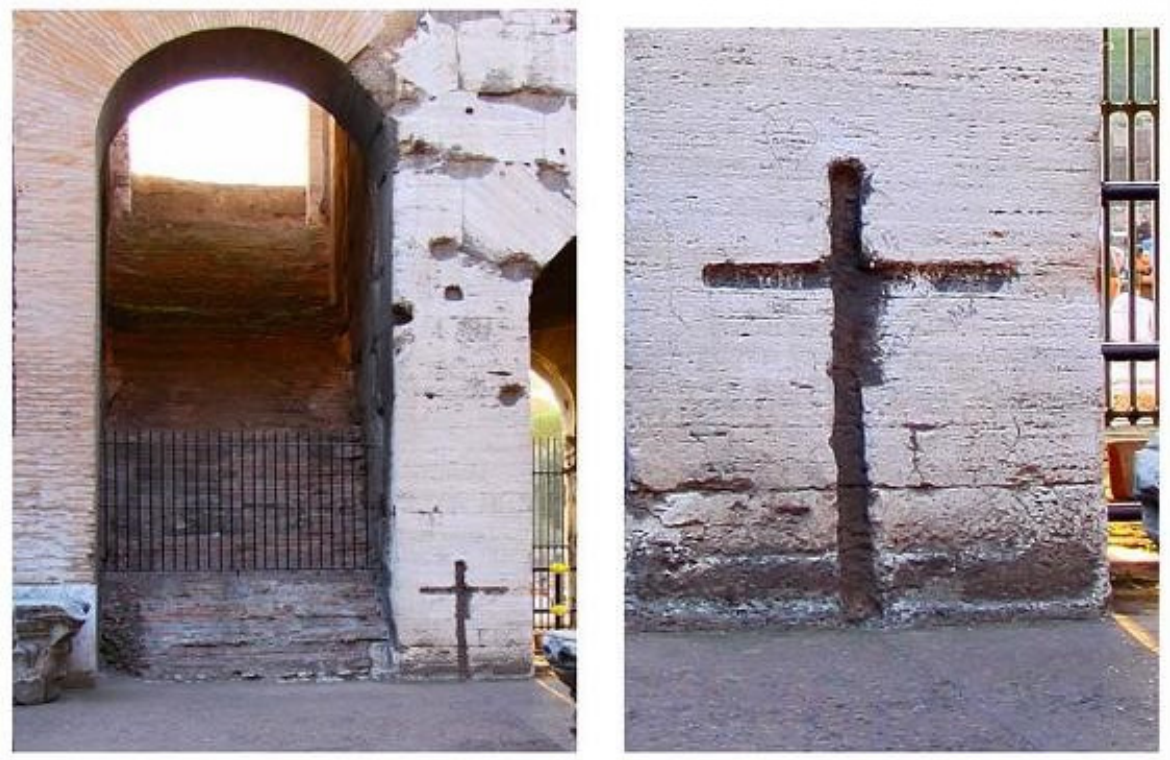

Figure 20. Traces of a public fountain in the Coliseum in Rome which tourists often interpret as a cross. The grooves contained the lead pipes that fed one of the dozens of fountains in the amphitheater (photo by Walter Dragoni).

The previous pages focused on the public fountains of ancient Rome, leaving aside imperial residences and villas of the dominant class, which were numerous and all equipped with monumental fountains. Even some private "middle class" buildings, often used for commercial purposes, had little private fountains located in the inner court. A good example is shown in Figure 21. 


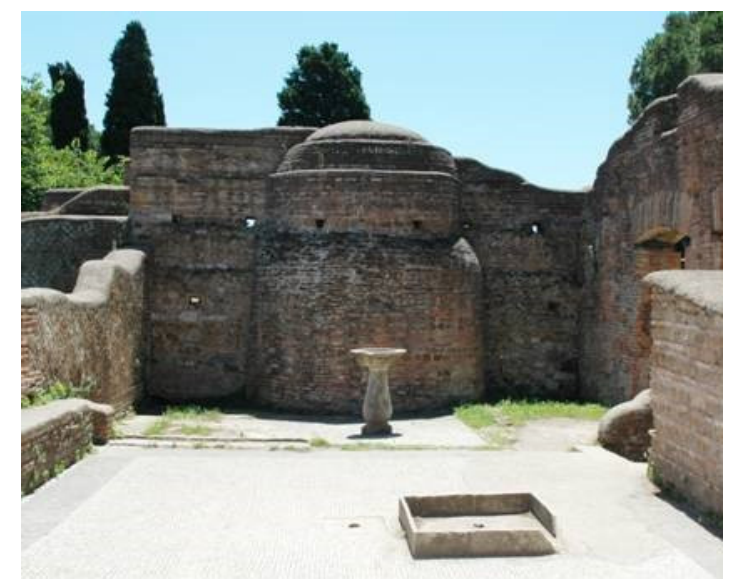

Figure 21. Fountain inside a private commercial building, a sort of restaurant, in Ostia, the harbor of Rome at the mouth of the Tiber River (photo by Walter Dragoni).

\section{Medieval Times}

\subsection{The Byzantine Period (ca. 4th c-15th c. AD)}

During the early Byzantine period, the structures and technologies of the fountains adhered to Roman tradition and customs. Fewer were constructed and the know-how of the past vanished. The densely built settlements also had less room for elaborate and impressive fountains.

On the other hand, the powerful and wealthy clergy of that period constructed well-designed fountains for churches and, especially, monasteries which survived raids and destruction because of their location (Figures 22 and 23).The typical fountains of that time were the simple arched niches either attached to a building wall or the more rare stand-alone ones where a stone or basin received the water flowing out of a simple or slightly ornamented spout.

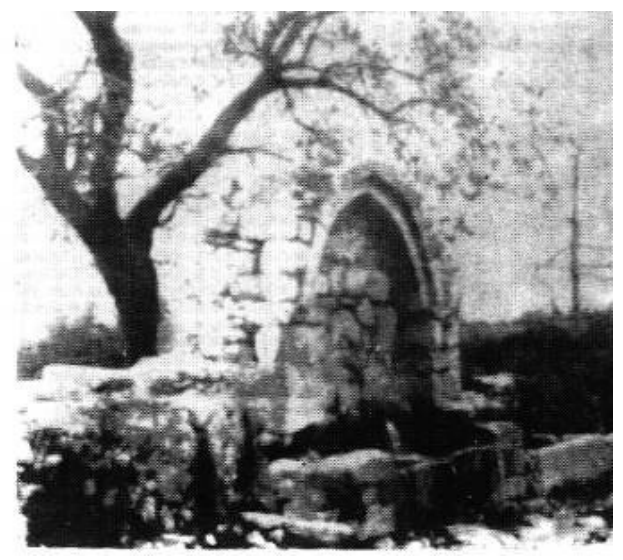

(a)

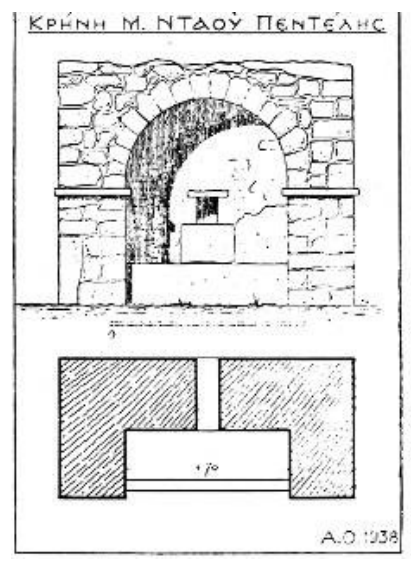

(b)

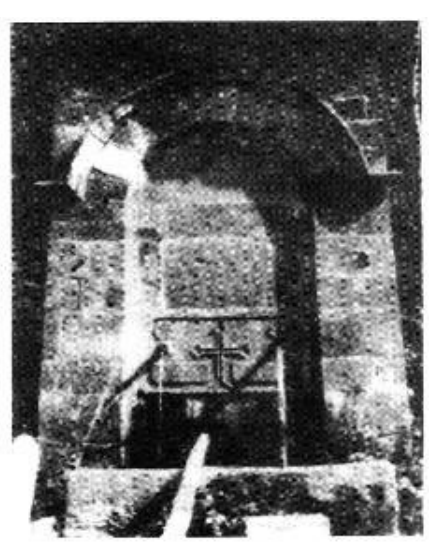

(c)

Figure 22. Typical structures of fountains in monasteries of the Byzantine period: (a) Faneromeni in Korinth; (b) Daou, Penteli, Attica; and (c) Filotheou in Mount Athos. 

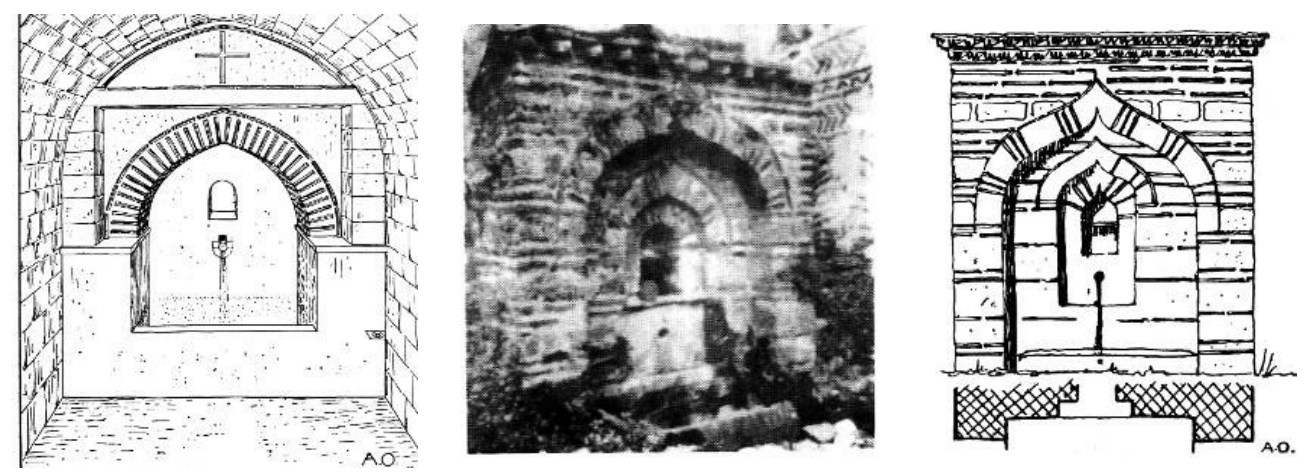

Figure 23. Typical structures of fountains in the Byzantine period.

Despite the general simplicity, there were also fountains constructed in a more elaborate manner. The stand-alone domed constructions embody the constructional technologies of the arches, domes, colonnades and tie beams of that period. The well elaborated examples also show the typical Byzantine types of masonry. As concerns water supply, it was implemented by the regular methods of the era as mentioned below (Figures 24 and 25):
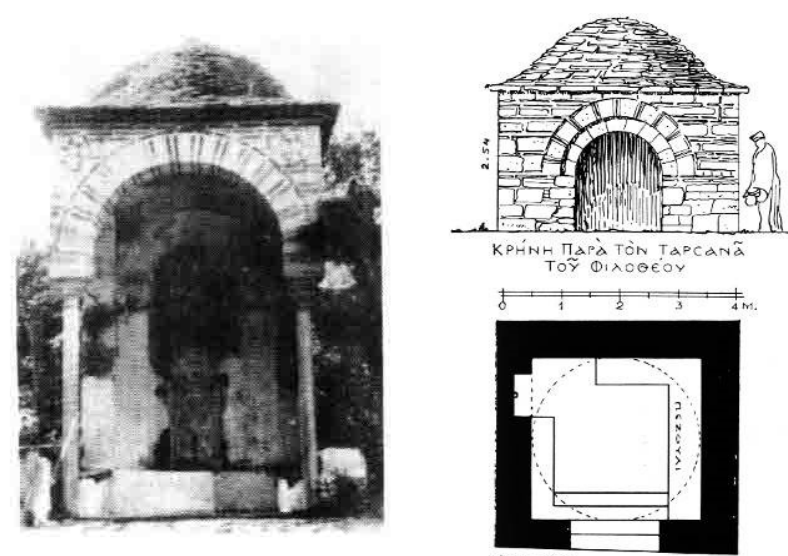

Figure 24. The well elaborated examples show also the typical Byzantine types of masonry.

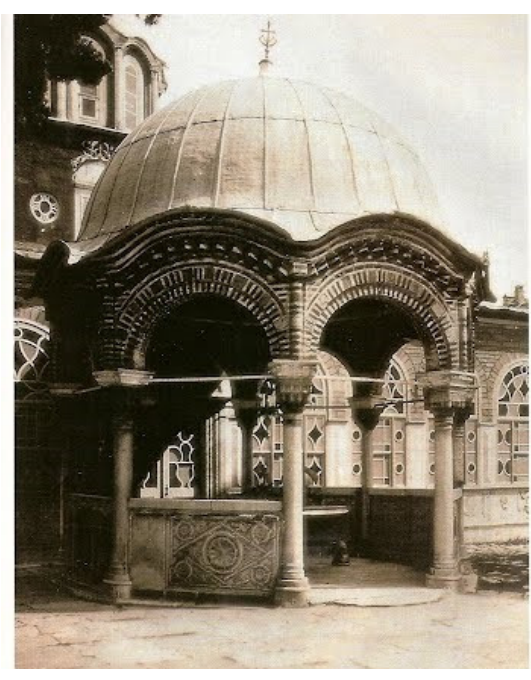

(a)

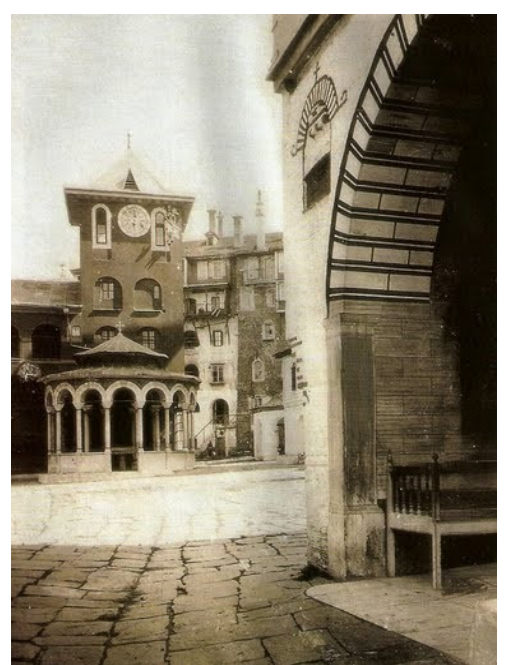

(b)

Figure 25. (a) Meg. Lavras Monastery (ca. 1060 AD) and (b) Batopedi Monastery. 
The most characteristic fountain of the Byzantine period is the "phiale". It had a dome which covered a circular shallow basin at the center, where the holy water was during the various rituals of the monastery. A low parapet separated the covered space from the yard around it. There was no natural flow of water to the basin. Yet, traces of the existence of a "strobilion" which jets water up at the center of the circular basin have been found.

Generally, the water supply for most fountains in Byzantium was provided through springs and pre-existing aqueduct systems. Most underground water harvesting networks had ceased operating or were no longer maintained. Thus, it is likely that the water conveyance systems were not operating well during the last period of the Byzantine Empire. Only in areas conquered by Westerners were the major supply systems functioning a little better.

\subsection{Medieval, Renaissance and Baroque Times in Western Europe (ca. 450-1700)}

After the fall of the Roman Empire, the great barbaric invasions transformed the empire into a multitude of independent little states, with ever changing boundaries and rulers, in a semi-permanent state of war. During these times, due to the combined effects of natural wear, lack of maintenance and wars, the great aqueducts fell into ruin: a great and complex aqueduct system can only be built and function in a region at peace under the control of one centralized political power with substantial economic resources [36]. With a few notable exceptions, none of these conditions existed in Western Europe from the 5th to the 15th century AD. Consequently, the great Roman fountains, as well as the networks of little city fountains built for public service, were in ruin all over Western Europe until about the 12th century AD. Water supply also generally declined significantly along with the number of the fountains. That is reflected in the scarcity of medieval fountains, which were small, simple, and often made of materials taken from ancient monuments. During the Early Middle Ages, water management was of high quality only in the East Roman Empire (i.e., the Byzantine Empire) and the Islamic kingdoms. In Western Europe, Islamic Spain had an excellent standard of water technology for irrigation, water supply and fountains. In Islamic Spain, old Roman aqueducts were repaired, new ones were constructed, and public and private fountains were built. The description of Islamic water management in Spain would require a separate book. Here, it must suffice to remember that Islamic culture adsorbed and applied Greek and Roman water technology. Under Islamic rule, new inventions were added to the ancient water technology, including the sophisticated pumps of Ibn al-Jazari, who lived $c a$. 11th-12th centuries AD [48]. Today, the fountains built in Spain under Islamic rulers constitute a well-known cultural attraction. They are in general much smaller than the great Roman ones, but they are fascinating for their grace and calm beauty (Figure 26).

In Medieval Western Europe, the technology for water supply and fountains was preserved thanks to the monasteries and abbeys. These were sort of autonomous communities, where water was needed for daily life, and often for irrigation of orchards and gardens. Gardens with fountains were seen as mystic places, a sort of earthly equivalent of Paradise (or the Garden of Eden), by both Christians and Muslims. In abbeys and monasteries, water was not only used for washing and other daily purposes, but also in the religious rite of cleansing hands before services and meals [49]. Wells were not efficient enough so, whenever possible, water was brought into religious communities and delivered through one or more fountains. As they were used simultaneously by many people, they had to have a large circular, polygonal or rectangular basin with multiple taps for discharging water (Figures 27 and 28). 


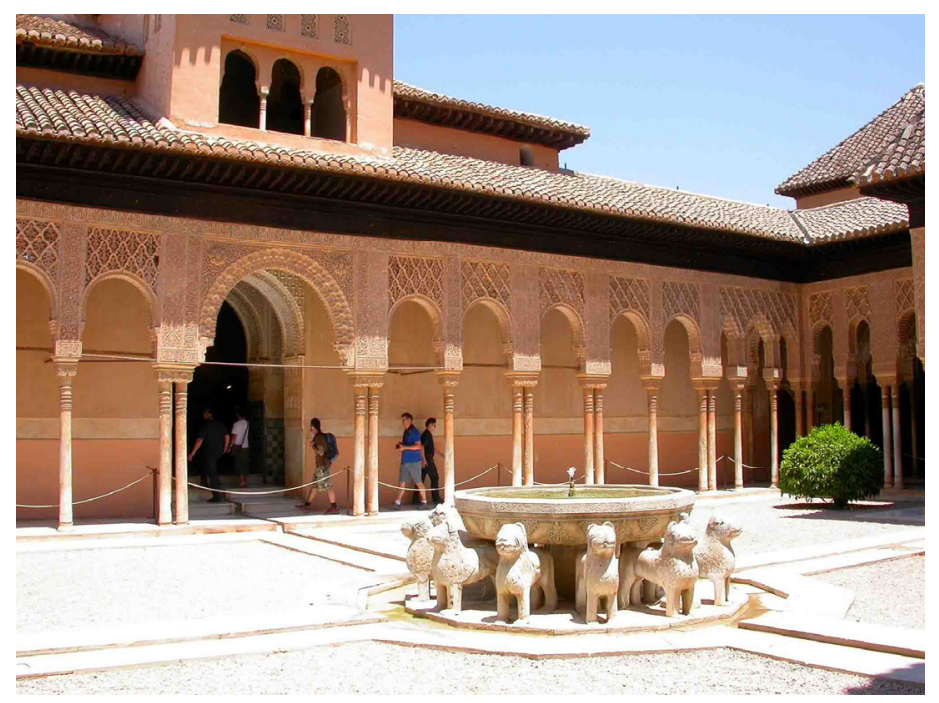

Figure 26. Granada, Alhambra, Fountains of the Lions, $c a$. 11th century AD (photo by Walter Dragoni).

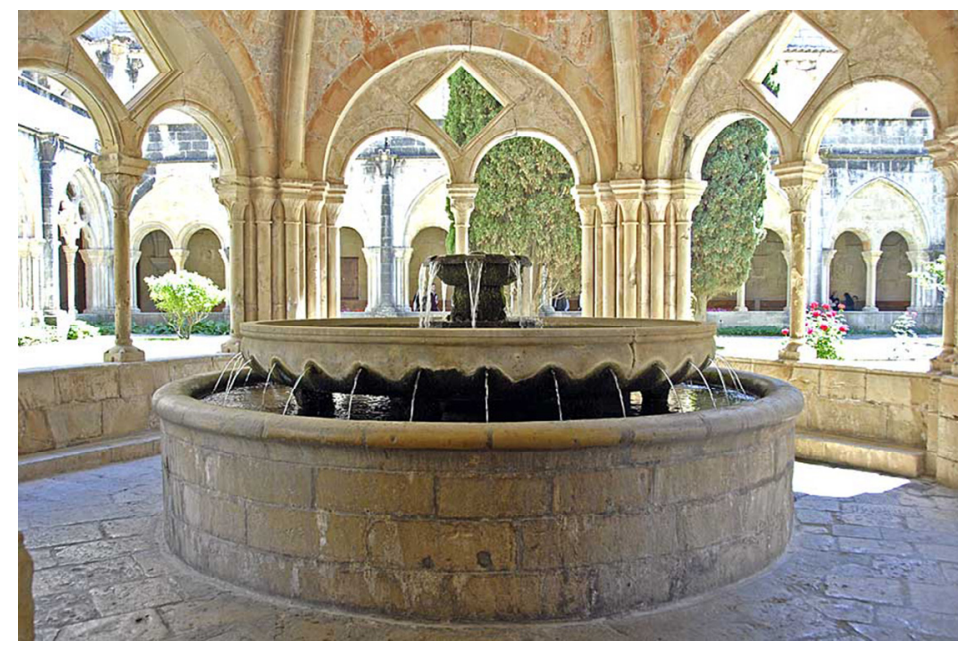

Figure 27. Lavatorium in the Monestir de Santa Maria de Poblet, municipality of Vimbodí and Poblet, Spain. (Photo (C) Adrian Fletcher, www.paradoxplace.com). [50].

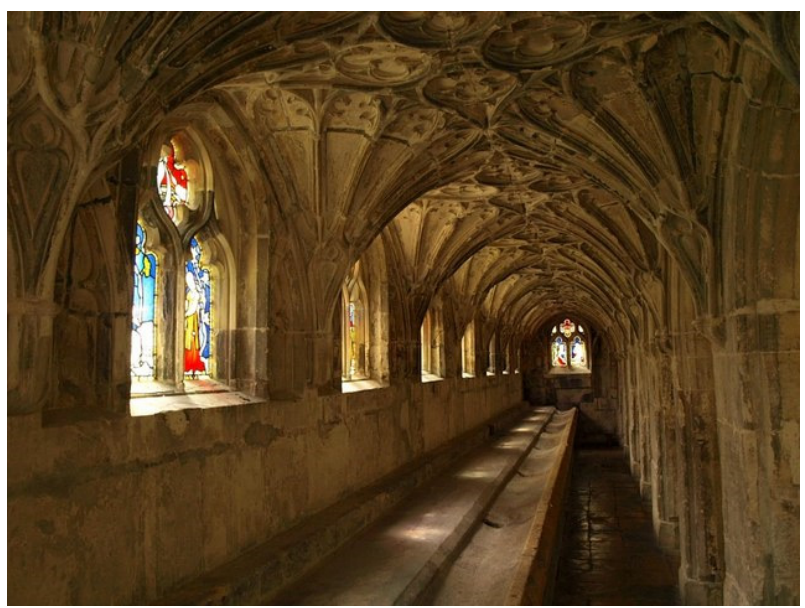

Figure 28. 14th century lavatorium at Gloucester Cathedral (photo by Derek Harper) [51]. 
This fountain type, called "lavatorium" from the Latin, is found throughout Europe. Thus, various archival documents from $c a$. 11th century give detailed information on their construction, especially in England. Many of these fountains still exist and have been studied by archaeological and engineering methods. In general, the fountains were fed by short aqueducts, usually taking water from springs located at a distance of a few kilometers. The pipes were commonly of lead and usually locally made using a technology similar to that of the Romans. If the water supplied to the religious community by the aqueduct exceeded its needs, the surplus was usually given for public consumption.

A new era for water supply systems and fountains began in northern and central Italy during the early 13th century $\mathrm{AD}$, when the communes (city-states) flourished [37]. At that time, following a period of mild climate (the so-called Medieval Warm Period) and the widespread use of the heavy plough [52,53] coupled with flourishing trade between the Levant and North Europe carried out by the Italian cities, urban population and wealth of the cities increased. Italian cities were considered the richest in Europe [37] then, and intense building activity started in most cities of any importance. Churches, public buildings and new city walls were built according to rational plans.

New water systems and fountains were also built, or old aqueducts were repaired and improved. During this period, fountains began to be increasingly built for public water supply and to adorn cities instead of for the purposes of religious communities. The importance of this change should not be underestimated. Here, we shall focus on the fountains in Umbria, a region in Central Italy, but the same applies to other areas in Italy. In order to appreciate the importance of these fountains, it is necessary to bring back to mind that between the 12th and14th centuries in Central Italy, the cities were only formally under the control of the Holy Roman Empire or the Pope. Furthermore, the cities of Umbria were not ruled by feudal lords, but by an oligarchy which included the nobility, merchants, and the productive classes. The cities (the communes) were a sort of complicated embryonic "democracies". Indeed, most of the rulers (called Consoli or Priori) were elected, and were in charge for a short time (six months or one year or so). Oftentimes, the Consoli were "professional politicians" from other cities. This was because, in theory, they had to govern in an objective manner in order to serve the whole community. Each city had a main square (piazza) where the cathedral and the Priori Palace, as well as other civil buildings, faced each other. They were the symbols of the religious and civil powers, located at the center of the city and society. The fountains built at the time are in the middle of the main piazza (square) between the symbols of religious and civil power, giving water to the entire community, not only to the upper classes.

Actually, religion and nobility always held overwhelming power, and the people of the lower classes were quite powerless. Nevertheless, the written documents, the architectural structure of the towns, and the public fountains indicate that the people felt that they were participating actively in the life of the city. In these conditions, between 1239 and 1319, fountains were built in the Umbrian towns of Spoleto, Trevi, Gubbio, Orvieto, Perugia, Assisi, and Narni, just to mention the principal ones. The building of these fountains implied a notable economic and technical effort, as often the towns were located on top of hills. The aqueducts are not more than a few kilometers long, but some times rather complex, as when they had siphons with pipes under high pressure. Their construction used and enhanced the best technical knowledge of that time. The fountains are all similar: water was generally led by a pressurized central pipe to an upper basin, from which it fell down to one or more lower basins. The lowest basin is a polygon, often decorated by sculptures of fine quality, or as in the case of the principal fountain of Perugia (Fontana Maggiore) of very high artistic value. The Fontana Maggiore of Perugia, considered 
a masterpiece of art, synthesizes the meaning of all contemporary fountains of the region. Therefore, it is the only one that is described in some detail.

The Fontana Maggiore, built in 1278 AD, consists of three decorated basins (Figure 29). The main artists who worked on the fountain are the sculptors Nicola and Giovanni Pisano, father and son. The fountain is located in the main square of Perugia, between the Cathedral and the Priori Palace, built soon after the fountain (Figure 30).

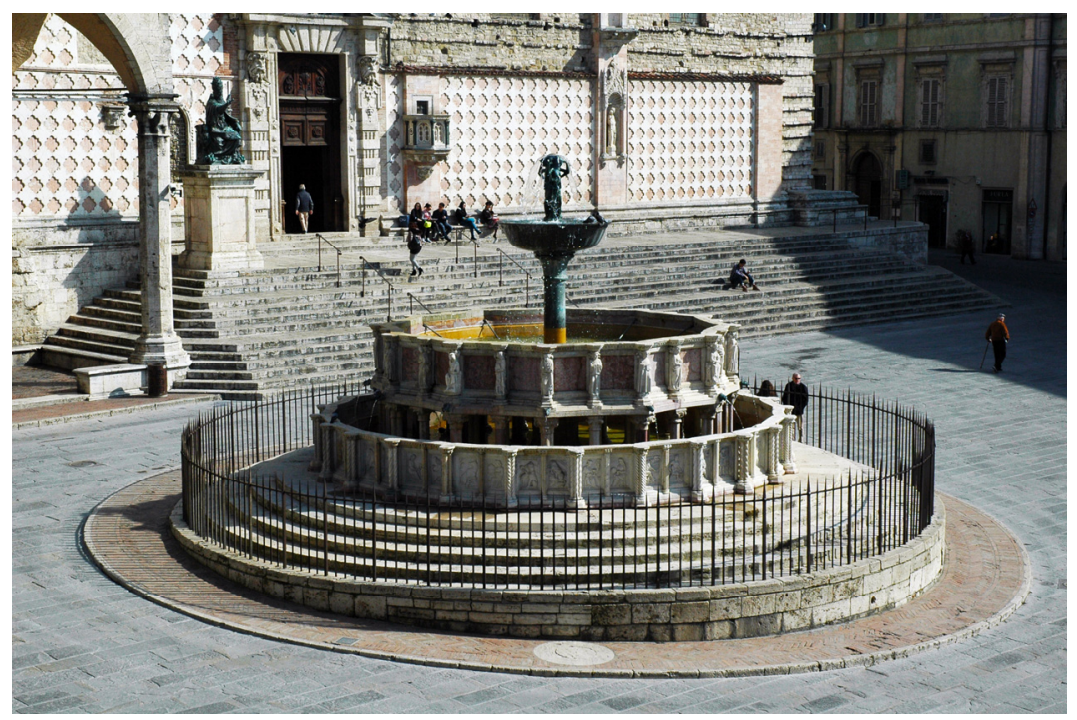

Figure 29. Fontana Maggiore, Perugia.

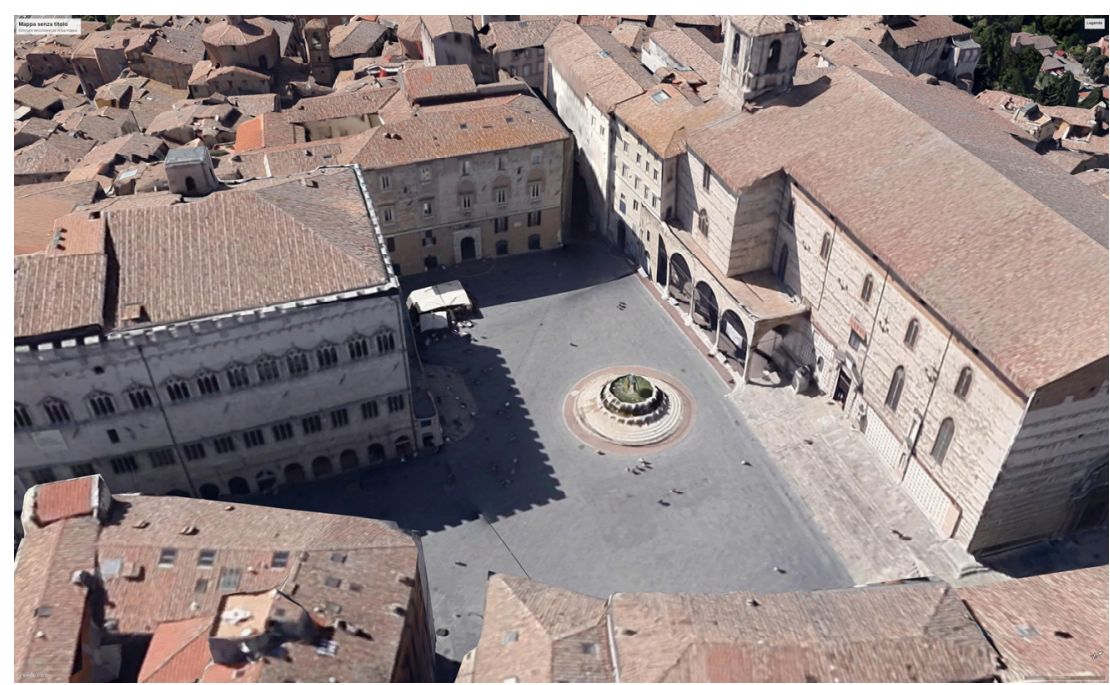

Figure 30. Location of Fontana Maggiore, Perugia. On the right, the Cathedral, on the left, the Palace of Priori. The fountain is at the center of the town, between the religious and the secular powers. (From Google Earth).

The lower basin has 25 sides, decorated with 50 bas-reliefs representing religious, historical, and mythological scenes. Besides them, the finest bas-reliefs present the types of work carried out each month of the year. For instance for February, the sculpture shows a fishing scene (Figure 31); for June, a wheat harvesting and hay mowing scene; for November, plowing and sowing; for December, the slaughter of a pig, and so on. 


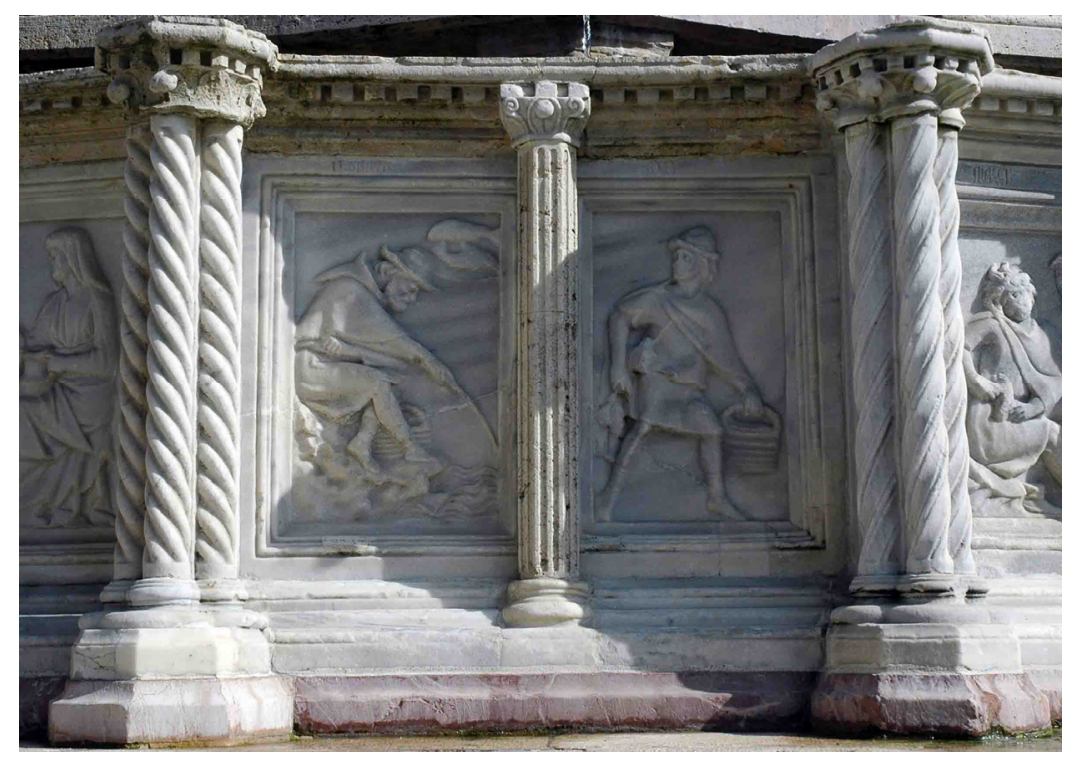

Figure 31. Fontana Maggiore, Perugia. Bas-relief for February.

The Fontana Maggiore, represents "noble" actions and situations as well as more humble ones: it gives water to the people regardless of their social position and is a hymn to labor and society in general. All arts, trades, and social strata of the town are included.

The Fontana Maggiore is not important only artistically and socially, but also technically. The spring feeding the fountain lies a few kilometers from the town on top of an isolated hill. The topography is such that a section of the aqueduct had to be constructed on high arches (Figure 32), and the maximum hydrostatic pressure on the lead pipes corresponded to about $100 \mathrm{~m}$ of water. In a way, such a bold construction effort, in spite of frequent pipe failures, marks the beginning of a new era for fountains, water supply and technical hydraulics. The aqueduct was completed between 1254 and 1277; the "engineers" in charge of its planning and construction, ignored by the history of hydraulics, were Boninsegna da Venezia and, later, Fra Bevignate (a Benedictine monk). The reader interested in the Fontana Maggiore can get further information from the vast available literature (e.g., [54,55]).

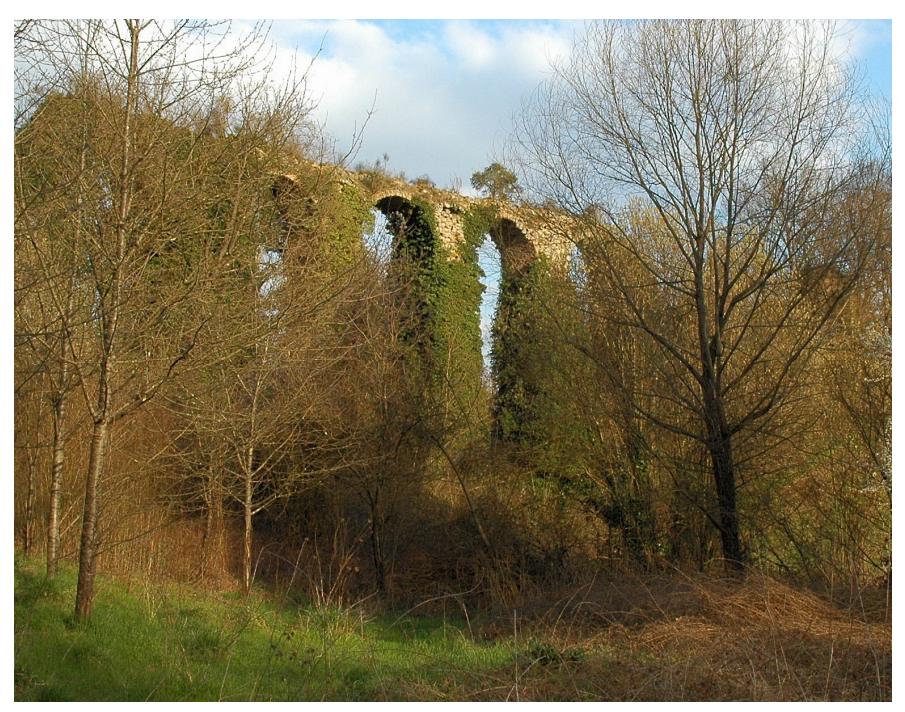

Figure 32. Surviving arches of the Fontana Maggiore aqueduct (photo by Walter Dragoni). 
The fountains built in Rome and Europe after the end of the 15th century defy any attempt of being described in a general paper like this. Hence, only a few general considerations and specific information about some fountains will be given.

In Rome, a few ancient aqueducts were repaired and some new ones built after the middle of the 15 th century. The time when fountains would be built not only for water supply, but also to adorn public places and to show power and wealth, was about to begin. Indeed, after the 15th century hundreds of artistic and monumental fountains were built in Rome including the fountains of Piazza Navona, Acqua Paola, Trevi. The interested reader is referred to the immense bibliography dealing with them, e.g., [35,56-58].

The fountain of Villa Medici (Figure 33) on the Pincio Hill is not among the most impressive Roman fountains, but it is important in the technical sense.

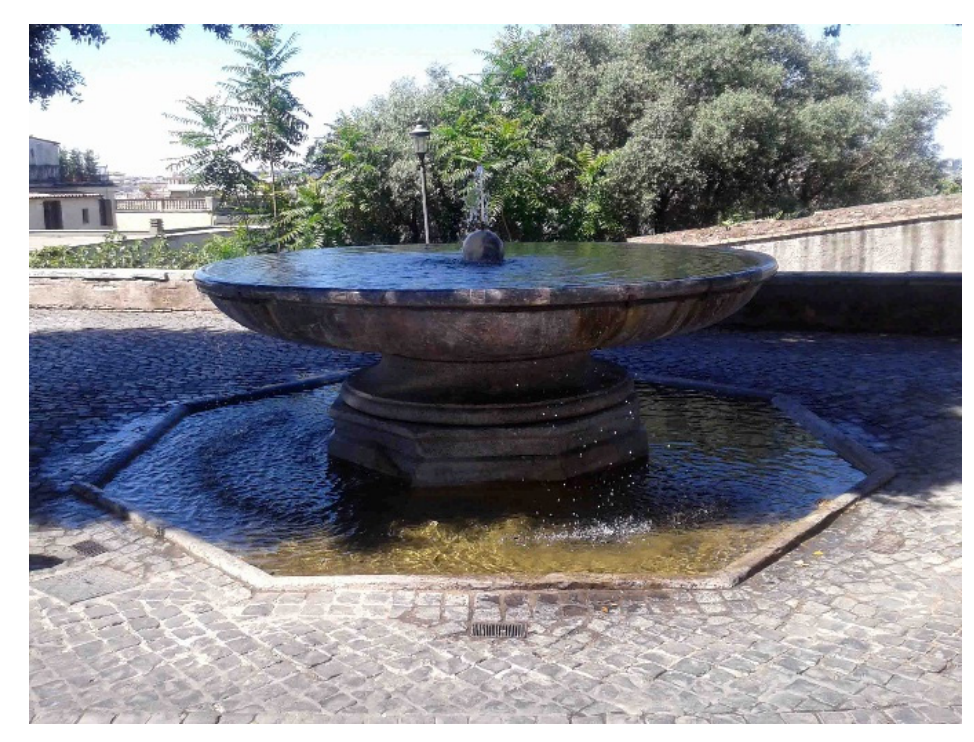

Figure 33. The Fountain of Villa Medici (photo by Pio Bersani).

This fountain known also as the Fontana della palla di cannone (Cannon Ball Fountain) was built in 1587 as an ornament for the main entrance to the villa owned by Cardinal Fernando Medici. The fountain could only be fed by the aqueduct of Aqua Virgo, which runs in a tunnel about $50 \mathrm{~m}$ below the level of the fountain [48]. Cardinal Fernando hired Camillo Agrippa, a well-known engineer and mathematician, to build a water lifting device to serve the Cannon Ball Fountain. Camillo Agrippa built the device consisting of at least one piston pump and pipes to deliver the water to the fountain. The pump was powered by a water wheel turned by the flowing water of the same aqueduct. Piston pumps were known in the Hellenistic and Roman world since $c a$. 3rd century BC, but up to present it appears there is no archaeological evidence of Greek o Roman piston pumps powered by water wheels. The Agrippa water lifting device, known in the Islamic world since at least the 12th century, appears to be the first known example built in Italy. Since then, water lifting devices of this type were used frequently when necessary. For further information about the Agrippa device, the interested reader is referred to the exhaustive research carried out by Lombardi [48].

The fountains built after 1500 in Rome and nearby localities, such as the splendid fountains of Villa d'Este in Tivoli (around 1550, Figure 34) and Villa Aldobrandini in Frascati (around 1600), contributed to the creation of the European fashion where parkland is decorated with great jeux d'eau, such as in 
Versailles, France (around 1660), Chatsworth in Derbyshire, England (around 1687) and the imperial park of Peterhof, close to St. Petersburg, Russia (around 1710-1720) [35].

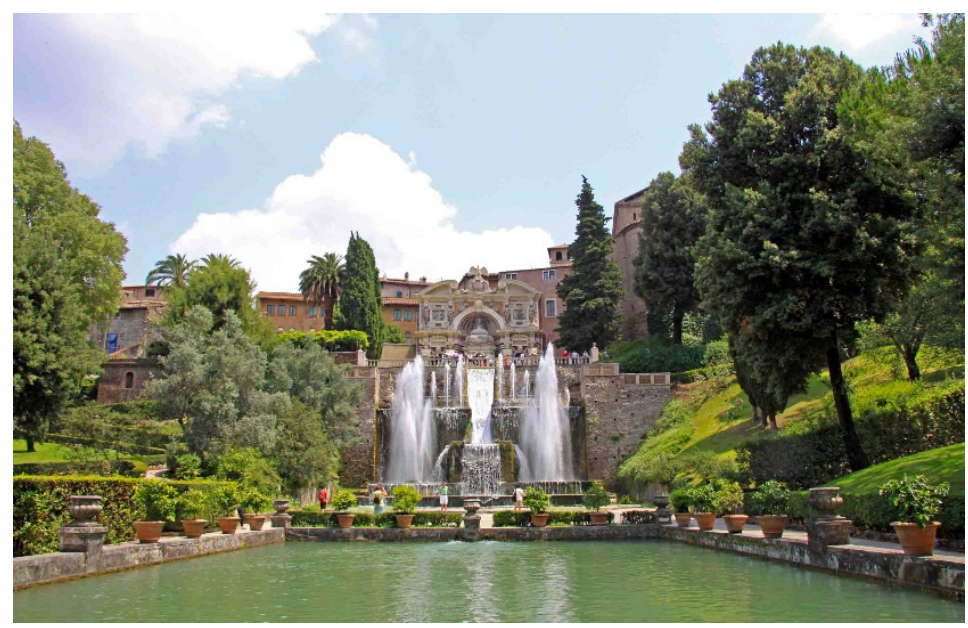

Figure 34. Fountain in the Villa d'Este park, in Tivoli, near Rome (photo by Walter Dragoni).

\subsection{Fountains and Islam}

In Islam, water is considered holy, a gift from God. Islam is a monotheistic religion based upon the Qur'an, and its Mosques have fountains where worshippers can wash themselves before entering the Mosque. The washing act is called "wudu". The Qur'anic mandate for "wudu" is expressed in the sixth ayat of sura 5 (Al-Ma'ida).

No one can refuse to give away surplus water without sinning against Allah and against man. The hadiths say that among the three people Allah will ignore on the Day of Resurrection will be the man who has water in excess of his needs, but refuses to give it to a traveler.

“We made from water every living thing” (Qur'an 21:30).

Water is the primary element that existed even before the heavens and the earth did:

"And it is He who created the heavens and the earth in sixth days, and his Throne was upon the water" (Qur'an 11:7).

The water of rain, rivers, and fountains runs through the pages of the Qur'an to symbolize God's benevolence:

"He sends down saving rain for them when they have lost all hope and spreads abroad His mercy" (Qur'an 25:48).

There are two fundamental precepts that govern the rights to water in the Shari ah. Shafa, the law of thirst, establishes the universal right for humans to quench their thirst and that of their animals; and shirb, the right of irrigation, gives all users the right to water their crops. From the numerous Quranic references to cooling rivers, fresh rain, and fountains of flavored drinking water in Paradise, we can deduce that water is the essence of the gardens of Paradise. It flows beneath and through them, bringing coolness and greenery, and quenches thirst. The believers will be rewarded for their piety. The water in Paradise 
is never stagnant; it flows, rushes, unlike the festering waters of Hell. The Qur'an also equates the waters of Paradise with moral uprightness. In the garden, there is no idle talk, and there is a gushing fountain [59].

Islamic Law, the Shari'ah, based on the teachings of the Qur'an and the prophet Mohammed, ensures democratic distribution of water in communities [60].

Ancient Persians already built water channels. These underground channels called Qanats were connected to smaller canals called karizs. These systems were used to lead water for household use and to irrigate farmland and gardens. Later, after the 7th century, gardenswere enclosed by walls to make them resemble paradise. These paradise gardens were laid out in the form of a cross, with the four arms representing the rivers of paradise that divide the world into four parts [61]. In some cases, water spouted from a fountain in the center of the cross representing the spring or fountain described in the Qu'ran as the source of the Paradise rivers [61].

\section{Modern Times}

\subsection{The Ottoman Period}

Water is part of the Ottoman religion. Cleansing of the body symbolizes the cleansing of the soul, according to the Koran [62]. Thus, a water fountain was located at the entrance of each mosque. Following the old Moslem tradition, public baths (hammams) and fountains were the major hydraulic works developed in several places during the Ottoman period. At that time (ca. 1669-1898 AD), Hammams occupied a key position in the Ottoman culture. They were used as places for meeting, cleaning and bathing, ritual cleansing, etc. The hammam is a very old Ottoman institution, and public baths were established all over the Ottoman Empire, including the Island of Crete [62].

Generally speaking, although a large quantity of water was needed for the hammams, no special effort was made to increase the quantity of water coming into major Cretan cities (e.g., Iraklion, Rethymnon, and Chania). The Venetian hydraulic works were just maintained in good condition. Thus, during the Ottoman period, the existing Venetian water cisterns and fountain houses remained in use and new ones were built. Tzombanakis [63] distinguished three different types of fountain houses: (a) large polygonal free-standing, elaborate fountain houses built by mosques (successors of the Christian phiale); (b) fountains usually built inside palaces and mosques; and (c) less elaborate fountain houses built by main roads and in villages.

During the period ( $\mathrm{ca}$. mid-14th century-1923 AD ) ruling pashas often built fountains next to mosques such as the Fountain of Qasim Pasha (1527); the one on Temple Mount, Jerusalem, an ablution and drinking fountain built during the Ottoman reign of Suleiman the Magnificent; and the Fountain of Ahmed III (1728), at the Topkap1 Palace, Istanbul. Of course, palaces also had small decorated fountains. They provided cool or hot air, drinking water, and made a calming and soothing sound. One surviving example is the Fountain of Tears (1764) at the Bakhchisarai Palace in Crimea made famous in a poem by Alexander Pushkin [64].

\subsection{Evolution of Fountains in Late Chinese Dynasties}

After the 1950s, along with the rapid urbanization of China, tap water replaced the well as the source of daily use in most places. Yet, the well has always played an important role in the water history of China. 
Spring water is also an important water resource in many places in China. Consequently, spring end structures have also assumed characteristics of fountains in China. The Chinese assign holy and spiritual meanings to springs; they are not merely sources of water. For example, a spring that is called a dragon pool is believed to be the house of the dragon, the God of Water.

Ji Nan City, the provincial capital of Shandong Province, is the city most famous for its springs in China: it has around 700 of them. They are not just water sources, but also special places with complex spiritual meanings. People have built pools around the outlets of these "fountains" and "sub-fountains", to watch and enjoy the gushing of the water. People have also constructed buildings and gardens in memory of famous people to enjoy their "fountains". In summer, watching gushing fountains brings great pleasure to citizens. For example, the history of the BaoTu Qian fountain dates back 2700 years. The fountain structure measuring $30 \mathrm{~m}$ long and $20 \mathrm{~m}$ wide was built over three spring outlets. In addition, a big garden with many buildings was built near the fountain in memory of saints and famous people, and for common people to enjoy the fountain (Figures 35 and 36) [65]. Even today many spring structures for daily water use are found in the city and the countryside.

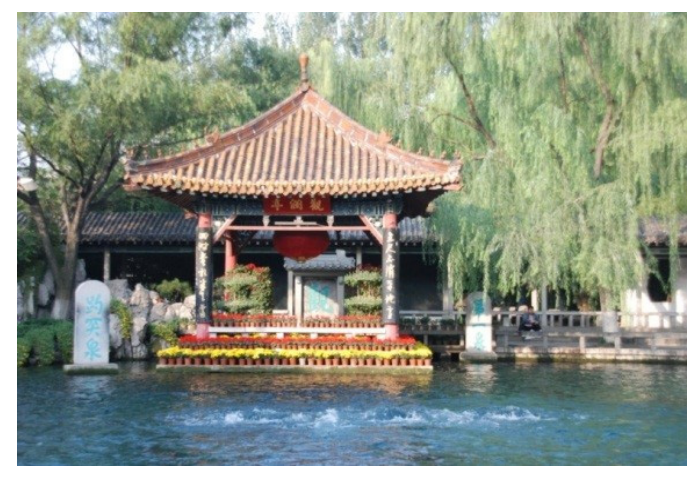

Figure 35. The BaoTu Qian fountain.

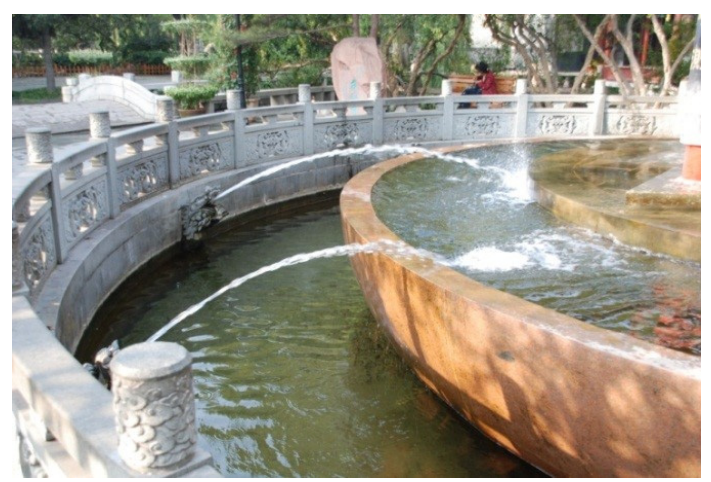

Figure 36. The fountain of Jinan City.

Another holy spring fountain in Yuxi Prefecture is the Nine-Dragon Fountain. The Nine-Dragon Fountain of Yuxi City, Yunnan Province, in Southwest China is a typical example of Chinese dragon fountain culture. It is located $10 \mathrm{~km}$ northwest of downtown Yuxi and comprises nine fountain outlets. The gushing volume of the fountain water is considerable all year round and forms a river called the Nine-Dragon River. Since its utilization started, it has been an important water source for local agriculture which has irrigated tens of thousands hectares of farmland. Since the outlets are surrounded by ominously quiet hills, dense forests, and crystal clear ponds, the scenery is wonderful (Figure 37). 


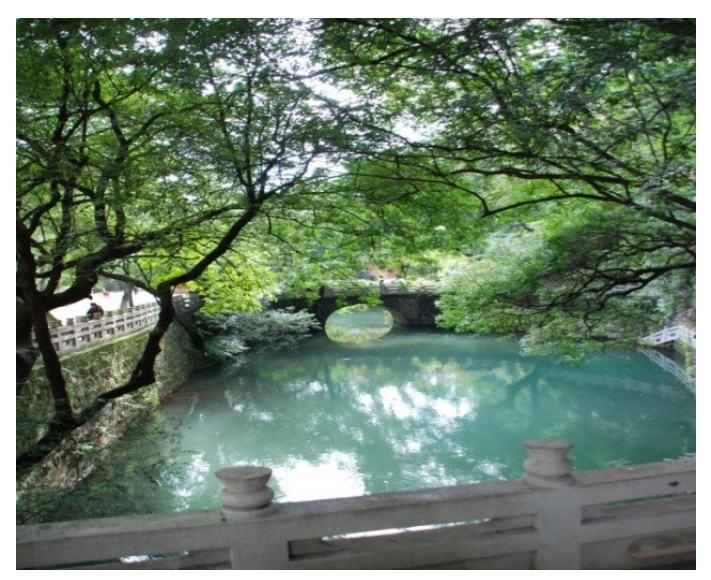

Figure 37. The main outlet of the Nine-Dragon fountain.

At the end of the Ming Dynasty about 300 years ago, people started building many religious and sightseeing buildings near the fountain. An oblong pond called the Large Dragon Pool, about $110 \mathrm{~m}^{2}$ in area, was built with stones at the outlet of the largest fountain. The main buildings include the "Nine-Dragon Palace", a temple dedicated to the dragon king; the "Five Si Temple" dedicated to the tiger, the monkey, the chicken, the sheep and the rabbit; the "Tower of Three Saints" dedicated to Sakyamuni, the founder of Buddhism, Lao Zi, the founder of Taoism, and Confucius, the founder of Confucianism, and the pavilion where tourists can listen to the sound of the water of the fountain.

Although the Nine-Dragon Fountain is a natural attraction, it also has profound cultural connotations derivingmainly from the relationship between the Chinese culture and water; it is a symbol of Chinese culture. Firstly, because it is linked to the most important natural god of Chinese culture, the Dragon. Chinese people believe that dragons live in fountains and spit out the fountain water, which is why they hold fountains sacred. According to a legend, the water is spit out by nine dragons, hence the name the "Nine Dragon Fountain" [65].

Many modern type fountains have been built in the cities which made them more beautiful and allowed citizens to enjoy the gushing waters. As they became a fashionable feature of urban design, more and more cities wanted them.

\subsection{Industrial Times}

Water and water fountains are used as cultural allegories. They are often assigned religious and other meanings. For example, in Christian allegory the fountain in "Fountain of Life" is associated with rebirth which happens after baptism. An interesting derivative of the Fountain of Life is the Fountain of Youth, from which one can drink to regain his youth or become immortal. Water fountains are also important for Muslims and Buddhists. Before the introduction of public waterworks, fountains supplied drinking and bathing water to the residents of cities. Yet, artists designed them to be aesthetically appealing. Fountains have always had a calming effect on people as they draw people to relax and socialize around them [5].

During the early history of modern public water systems in the ca. 19th and even the 20th century, water from fountains was also used for productive purposes, such as to water animals in Tampere, Finland. In Victoria, Canada, fountains erected near the turn of the 20th century had different levels for 
various users of water. The fountains provided water not only for travellers and their thirsty horses but also for smaller animals such as dogs and pigs [66].

The water fountain in Trafalgar Square in London, UK, is nowadays a popular destination of sightseeing tours, which resembles the Canaletes Fountain in Plaza Catalunya in Barcelona. Over the years, Trafalgar Square has accumulated additional statues and other works of art. The original Trafalgar Square Fountain erected in 1845 was remolded in 1939, and is actually a set of two fountains. The Trafalgar Square Fountain features mermen and mermaids alongside dolphins, all sculpted in bronze. As pointed out on the city web page: “...this is a popular tourist attraction. Best of all; it is free!" Since its construction, Trafalgar Square has also been a venue of political demonstrations [67].

New types of high-tech fountains, called "water kiosks", have begun to spread in some European countries since the beginning of the twenty-first century [3]. The water they dispense from an aqueduct undergoes certain treatments (active carbon, cooling, addition of carbon dioxide) to improve its organoleptic characteristics such as smell, taste, and temperature. That reduces the use of bottled water and the resulting generation of waste (PET bottles) as well as the $\mathrm{CO}_{2}$ emissions associated with the transport of the bottles from bottling plants to the consumer. These kiosks have met wide approval in Italy, from the public and municipal authorities alike, to the point that over the last ten years their number has gone from zero to over a thousand, especially in the northern and central parts of the country. A water kiosk in the Turin area is shown in Figure 38 [68].

A water fountain made for fun and aesthetic enjoyment is shown in Figure 39.

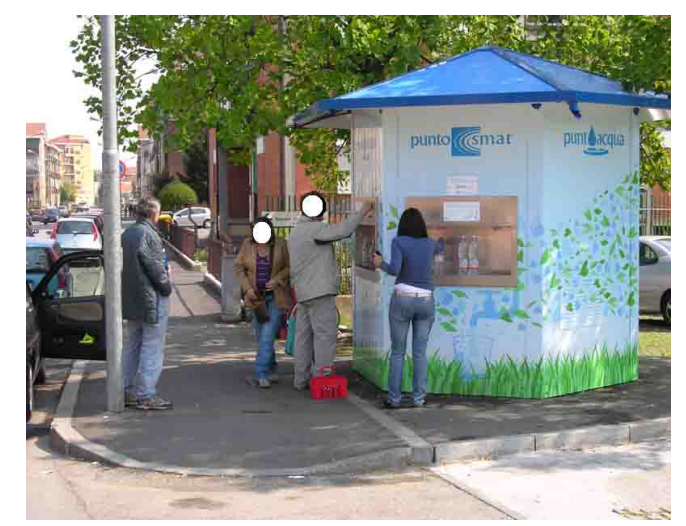

Figure 38. Water Kiosk in a park in Turin (with permission of SMAT SpA).

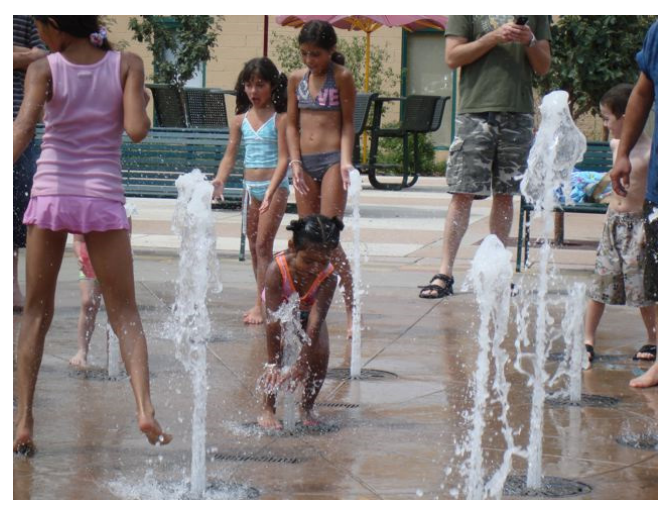

Figure 39. Children enjoying fountains with changing flows and jets in Arvada, Colorado, US (Photo: Dave Hendricks 2008). 


\section{Discussion}

The Minoans of Crete, the center of Europe's first advanced civilization, developed the first advanced hydraulic engineering applications. In the early phases, fountains were used especially for public water supply. The roots of Roman hydraulic technology were in the Etruscan civilization and contemporary mural paintings even suggest the existence of pressure pipes.

In ancient Greek cities, shrines and fountains were associated mainly with social and public life and religious beliefs about gods and nymphs living by water. Most Greek fountains used gravity flow, but water pressure and the siphoning principle were also used to make water jet or spout.

Ancient Rome is known for its aqueducts and public fountains - In the fourth century, during a deep decline, it still had 1352 fountains or cisterns. Fountains were also common in the private houses of wealthy families. The numerous imperial residences and villas were all equipped with monumental fountains. Even some private "middle class" homes had little private fountains in the inner court. More than forty public fountains of Pompeii, the city destroyed by the Vesuvius eruption in 79 AD, have been discovered so far.

In the early 13 th century, communes (city-states) in northern and central Italy built new water systems and fountains or repaired old aqueducts. Fountains were increasingly built for public water supply and to adorn cities and placed in the middle of the main piazza (square) between the symbols of religious and political power. Various sources indicate that the people participated actively in the life of the cities.

Hundreds of artistic and monumental fountains were built in Rome after the 15th century including the famous fountains of Piazza Navona, Acqua Paola, and Trevi. The splendid fountains of Villa d'Este in Tivoli (ca. 1550) and Villa Aldobrandini in Frascati (ca. 1600) gave rise to the European fashion of adorning parkland with great jeux d'eau, such as in Versailles, France (ca. 1660), Chatsworth in Derbyshire, England (ca. 1690) and Peterhof, next to St. Petersburg in Russia (ca. 1710-1720).

During the early history of modern public water systems in the 19th and even the 20th century, water from fountains was also used for productive purposes, such as to water animals. The water fountain in Trafalgar Square in London, UK, is nowadays a popular destination of sightseeing tours. More recently new types of high-tech fountains, called "water kiosks", have spread across some European countries to provide safe drinking water. Recently, many fascinating fountains have also been designed for fun and aesthetic enjoyment.

Water fountains have had and continue to have major religious significance such as the "phiale" in the Byzantine period. Gardens with fountains have been mystical places, sort of earthly equivalents of Paradise, for both Christians and Muslims. Islamic mosques have fountains where worshippers can wash themselves before entering. The Chinese assign holy and spiritual meanings to springs called dragon pools.

Fountains have also been symbols of power and wealth which have spread to public buildings and private residences as shown by existing examples. In our built environment, flowing water and fountains seem to be a calming element in many respects. 


\section{Conclusions}

Undoubtedly, a wide variety of fountains have been built over time. On the whole, the emphasis has shifted, or rather expanded, over time along with societal development from just meeting basic needs, such as providing drinking water for people and animals, more towards providing enjoyment and aesthetic values.

The aim of this paper is not to give an exhaustive account of the history of fountains in various parts of the world until today. Instead it presents some characteristic fountains of different civilizations chronologically. Historical fountain technologies may have useful applications even in today's water engineering. Some lessons learned include:

(a) Throughout history, fountains have been an essential part of water supply that provides water resources sustainability for the survival and well-being of humans. Thus, ancient fountains should be considered, not only historical artifacts, but also potential models for sustainable water technologies now and in the future.

(b) Ancient water technologies, including fountains and well- or cisterns-like fountains, were characterized by simplicity, ease of operation, and lack of complex controls, which makes them more sustainable. However, they have lost some of their importance for modern water supply purposes in the developed parts of the world, whereas they are more applicable in the developing parts of the world [8].

In conclusion, globally some 0.8 billion people lack safe water, more than 2.6 billion people do not use improved sanitation and 1.1 billion practice open defecation. Thus, there is a huge need for sustainable and cost-effective water supply and sanitation facilities, such as fountains, particularly in the cities of the developing world [69]. The applicability of select ancient technologies in the contemporary developing world should, therefore, be seriously considered.

\section{Acknowledgments}

We thank Academy of Finland AKVA project Water as Social and Cultural Space (No. 263417) for their support. The chapters on Etruria, Rome and the Middle Ages in Western Europe were supported by Provincia di Perugia and Fondazione Cassa di Risparmio di Perugia (project 2010.011.0442, coordinated by W. Dragoni).

\section{Author Contributions}

Author Contributions are: Petri S. Juuti: Fountains in general. Georgios P. Antoniou: Fountains in general; Walter Dragoni: Case expert of Italy and Western Europe; Fatma El-Gohary: Fountains in general; Giovanni De Feo: Fountains in general; Tapio S. Katko: Fountains in general; Riikka P. Rajala: Fountains in general; Xiao Yun Zheng: Case expert of China; Renato Drusiani: Fountains in general; Andreas N. Angelakis: Case expert of Greece.

\section{Conflicts of Interest}

The authors declare no conflict of interest. 


\section{References}

1. Mays, L.W.; Koutsoyiannis, D.; Angelakis, A.N. A brief history of urban water supply in antiquity. Water Sci. Technol. Water Supply 2007, 7, 1-12.

2. Angelakis, A.N.; Spyridakis, S.V. Major Urban Water and Wastewater Systems in Minoan Crete, Hellas. Water Sci. Technol. Water Supply 2013, 13, 564-573.

3. Histoire des Jardins; Ouest, S., Ed.; PREVOT, Philippe: Bordeaux, France, 2006. (In French)

4. SAMIRAD. Saudi Arabia Market Information Resource Directory. Available online: http://www. saudinf.com/index.htm (accessed on 21 March 2015).

5. Hynynen, A.J.; Juuti, P.S.; Katko, T.S. Water Fountains in the World scape; Hynynen, A.J., Juuti, P.S., Katko, T.S., Eds.; International Water History Association (IWHA): Delft, The Netherlands, 2012.

6. Angelakis, A.N.; Koutsoyiannis, D.; Papanikolaou, P. On the geometry of the Minoan water conduits. In Proceedings of the 3rd IWA International Symposium on Water and Wastewater Technologies in Ancient Civilizations, Istanbul, Turkey, 22-25 March 2012; pp. 172-177.

7. Evans, S.A. The Palace of Minos at Knossos: A Comparative Account of the Successive Stages of the Early Cretan civilization as Illustrated by the Discoveries, (Vol. I-IV); Macmillan and Co.: London, UK, pp. 1921-1935.

8. Angelakis, A.N. The History of Fountains and Relevant Structures in Crete, Hellas. J. Glob. Environ. Issues 2015, in Press.

9. Angelakis, A.N.; Spyridakis, S.V. The status of water resources in Minoan times: A preliminary study. In Diachronic Climatic Impacts on Water Resources with Emphasis on Mediterranean Region; Angelakis, A.N., Issar, A.S., Eds.; Springer-Verlag: Heidelberg, Germany, 1996; Chapter 8, pp. 161-191.

10. Platon, E. Minoan terracotta water spouts. In Proceedings of the 7 th International Congress of Cretan Studies, Rethymnon, Greece, 25-31 August 1991; pp. 767-775. (In Greek)

11. Angelakis, A.N.; Dialynas, M.G.; Despotakis, V. Evolution of water supply technologies in Crete, Greecethrough the centuries. In Evolution of Water Supply throughout Millennia; Angelakis, A.N., Mays, L.W., Koutsoyiannis, D., Mamassis, N., Eds.; IWA Publishing: London, UK, 2012; Chapter 9, pp. 227-258.

12. Angelakis, A.N.; Kavoulaki, E.; Dialynas, M.G. Sanitation and Stormwater and Wastewater Technologies in MinoanEra. In Evolution of Sanitation and Wastewater Management through the Centuries; Angelakis, A.N., Rose, J., Eds.; IWA Publishing: London, UK, 2013; Chapter 1, pp. 1-24.

13. Floods, J. Water Management in Neopalatial Crete and the Development of the Mediterranean climate. Master's Thesis, The University of North Carolina, Greensboro, NC, USA, 2012.

14. Betancourt, P. Pseira IX: The Archaeological Survey of Pseira Island Part 2; INSTAP Academic Press: Philadelphia, PA, USA, 2005.

15. Hirst, B.R. Fountains; Kingston University: London, UK, 1996.

16. Hodge, A.T. Roman Aqueducts \& Water Supply, 2nd ed.; Gerald Duckworth: London, UK, 2002.

17. Castellani, V.; Dragoni, W. Opere Arcaiche per il controllo del territorio: Gli emissari sotterranei artificiali dei laghi Albani. In Gli Etruschi Maestri di Idraulica; Bergamini, M., Ed.; ELECTA: Venezia, Italy, 1991; pp. 43-60. (In Italian) 
18. Bersani, P.; Canalini, A.; Dragoni, W. First results of a study of the Etruscan tunnel and other hydraulic works on the "Ponte Coperto" stream (Cerveteri, Rome, Italy). Water Sci. Technol. 2010, $10,561-569$

19. Howard Hayes, S. Etruscan Cities \& Rome; Cornell University Press: Ithaca, NY, USA, 1967; p. 320.

20. Maggiani, A. Le fontane nei santuari d'Etruria. In Il Fanum Voltumnae e i Santuari Comunitari Dell'Italia Antica; Fina, G.D., Ed.; Edizioni Quasar: Roma, Italy, 2012; Volume XIX, pp. 265-292. (In Italian)

21. Inghirami, F. Pitture di Vasi Fittili, Volume 2; Nabu Press: Fiesole, Italy, 1833. (In Italian)

22. Agguato di Achille a Troilo. Available online: http://it.wikipedia.org/wiki/Tomba_dei_Tori\# mediaviewer/File:Etruscan_mural_achilles_Troilus.gif (accessed on 21 March 2015).

23. Jiao, J.J. A 5600-year-old wooden well in Zhejiang Province, China. Hydrogeol. J. 2007, 15, 1021-1029.

24. The Old Han Well Found in the Worksite. Yeng Zhao Night Daily, 30 April 2010.

25. Liu, S. A Exploring on Form of Chinese Old Well. Agric. Archaeol. 1991. (In Chinese)

26. Polyxene Louvre. Available online: http://en.wikipedia.org/wiki/File:Polyxene_Louvre_F366.jpg (accessed on 21 August 2013).

27. Elderkin, G.W. The Fountain of Glauce at Corinth. Am. J. Archaeol. 1910, 14, 19-50.

28. WaterHistory Home Page. Available online: http://www.waterhistory.org/ (accessed on 21 August 2013).

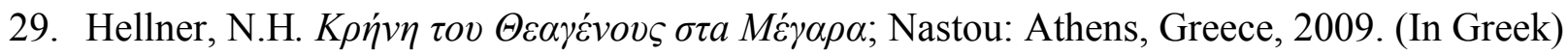

30. Antoniou, G.P. Ancient Greek Lavatories: Operation with Reused Water. In Ancient Water Technologies; Mays, L.W., Ed.; Springer: Dordrecht, The Netherlands, 2010.

31. Thompson, H.; Wycherley, R.E. The Athenian Agora, The Agora of Athens: The History; Shape and Uses of an Ancient City Center: Athens, Greece, 1972; pp. 194-203.

32. Castalian Spring. Available online: http://wikipedia.org/wiki/Castalian_Spring (accessed on 21 March 2015).

33. Frontin. Les Aqueducs de la Ville de Rome, Translation and Commentary by Pierre Grimal; Société d'édition Les Belles Lettres: Paris, France, 1944. (In France)

34. Pace, P. Gli Acquedotti di Roma; Art Studio S. Eligio: Roma, Italy, 1983; p. 330. (In Italian)

35. Dragoni, W. Rome's Fountains: Beauty and Public Service from Geology, Power and Technology. In Water Fountains in the Worldscape; Hynynen, A.J., Juuti, P.S., Katko, T.S., Eds.; IWHA: Delft, The Netherlands, 2012; pp. 18-33.

36. Castellani, V.; Dragoni, W. Opere Idrauliche Ipogee nel Mondo Romano: Origine, Sviluppo e Impatto nel Territorio. L'UNIVERSO 1989, LXIX, 100-137. (In Italian)

37. Pounds, N.J.G. An Historical Geography of Europe 450 B.C.-A, Parte 1330; Cambridge University Press: Cambridge, UK, 1973; p. 475.

38. Keenan, D. Water supply and wastewater disposal in Pompeii: An Overview. Anc. Hist. 2004, 34, 149-158.

39. Jansen, G.C.M. Urban Water Transport and Distribution. In Handbook of Ancient Water Technology; Wikander, Ö., Ed.; BRILL: Leiden, The Netherlands, 2000; p. 741. 
40. De Feo, G.; Laureano, P.; Drusiani, R.; Angelakis, A.N. Water and wastewater management technologies through the centuries. Water Sci. Technol. Water Supply 2010, 10, 337-349.

41. De Feo, G.; Mays, L.W.; Angelakis, A.N. Water and Wastewater Management Technologies in the Ancient Greek and Roman Civilizations. In Treatise on Water Science; Wilderer, P., Ed.; Academic Press: Oxford, UK, 2011; Volume 4, pp. 3-22.

42. De Feo, G.; de Gisi, S.; Malvano, C.; Tortora, A.; del Prete, S.; Maurano, F.; Tropeano, E. The Roman aqueduct and the Helvius' Fountain in Sant'Egidiodel Monte Albino, in Southern Italy: A historical and morphological approach. In Proceedings of the 2nd IWA International Symposium on Water and Wastewater Technologies in Ancient Technologies, Bari, Italy, 28-29 May 2009.

43. Pompeii. Fountain outside VII.1.32 and VII.1.33. Excavated 1846. Available online: http://www. pompeiiinpictures.com/pompeiiinpictures/Fountains/Fountain\%2070132.htm (accessed on 21 March 2015).

44. Jashemski, W.F. The Use of Water in Pompeian Gardens. In Proceedings of the 9th History of Water Management and Hydraulic Engineering in the Mediterranean Region, Pompeii, Italy, 1-8 October 1994; pp. 51-57.

45. Prakoso, S. The Laurentine Villa and the Tuscan Villa of Pliny the Younger. Jurnal Ilmiah Arsitektur UPH 2006, 3, 130-142. (In Bahasa)

46. Mari, Z.; Sgalambro, S. The Antinoeion of Hadrian's Villa: Interpretation and Architectural Reconstruction. Am. J. Archaeol. 2007, 111, 83-104.

47. Lombardi, L.; Corazza, A. L'acqua e la città in epoca antica. In "La Geologia di Roma, dal Centro Storico alla Periferia”, Part I Memorie Serv. Geol. d'Italia; S.E.L.C.A: Firenze, Italy, 2008; Volume LXXX, pp. 189-219. (In Italian)

48. Lombardi, L. Camillo Agrippa's Hydraulic Inventions on the Pincian Hill (1574-1578). Available online: http://www3.iath.virginia.edu/waters/Journal5LombardiNew.pdf (accessed on 21 March 2015).

49. St. John Hope, W.H.; Fowler, C.J.T. Recent discoveries in the Cloister of Durham Abbey. Archaeologia 1903, 58, 437-460.

50. Lavatorium. Available online: http://www.paradoxplace.com/Photo\%20Pages/Spain/Navarre Aragon_Catalonia/Catalonia/Poblet/Images/800/Lavatorium2-Jun06-D9807sAR900.jpg (accessed on 29 April 2015).

51. Lavatorium, Gloucester Cathedral Cloisters. Available online: http://commons.wikimedia.org/ wiki/File:Lavatorium,_Gloucester_Cathedral_Cloisters_-_geograph.org.uk_-_876615.jpg\#file (accessed on 29 April 2015).

52. Andersen, T.B.; Jensen, P.S.; Skovsgaard, C.S. The Heavy Plough and the Agricultural Revolutionin Medieval Europe; Discussion Papers on Business and Economics, No. 6/2013; University of Southern Denmark: Copenhagen, Denmark, 2013; p. 69.

53. Dragoni, W. Some considerations on climatic changes, water resources and water needs in the Italian region south of the $43^{\circ} \mathrm{N}$. In Water, Environment and Society in Times of Climatic Change; Issar, A., Brown, N., Eds.; Kluwer: Alphen aan den Rijn, The Netherlands, 1998; pp. 241-271.

54. Cavallucci, F. La Fontana Maggiore di Perugia: Voci e Suggestioni di Una Comunità Medievale; Quattroemme: San Giovanni, Italy, 1993; p. 237. (In Italian) 
55. Soletti, A. L'acquedotto medievale di Perugia. Quaderno 5-Laboratorio di Disegno Automatico, Università di Perugia; Soletti, A., Ed.; Istituto di Disegno Architettura Urbanistica: Perugia, Italy, 1992; p. 94. (In Italian)

56. D’Onofrio, C. Le Fontane di Roma, con Documenti e Disegni inediti; Staderini Editore: Roma, Italy, 1962; p. 309. (In Italian)

57. Cope, F. Fontane di Roma; Rizzoli Libri Illustrati, GruppoSkira: Ginevra, Switzerland, 2004; p. 207. (In Italian)

58. Rinne, K.W. The Waters of Rome: Aqueducts, Fountains, and the Birth of the Baroque City; Yale University Press: New Haven, CT, USA, 2011; p. 262.

59. Islamonline Homepage. Available online: www.islamonline.net (accessed on 21 March 2015).

60. Encyclopaedia Britannica Online. Tunis: Encyclopædia Britannica. Available online: http://www.britannica.com/EBchecked/topic/609220/Tunis (accessed on 21 August 2013).

61. Yves-Marie, A.; Christiany, J. L'Art des Jardins en Europe; Citadelles \& Mazenod: Paris, France, 2006. (In France)

62. Kanetaki, E. Ottoman Baths in the Greek Territory; Technical Chamber of Greece: Athens, Greece, 2004. (In Greek).

63. The Cretan Architecture the 18th and 19th Centuries; Chryssoula Tzobanaki: Iraklion, Greece, 2005; Volume A1. (In Greek).

64. Fountains of the Islamic World. Available online: http://www.watercharm-cn.com/plus/ view.php?aid=165 (accessed on 21 March 2015).

65. Zheng, X.Y. Meeting Place of Chinese Culture and Water: The Case of the Nine-Dragon Fountain of Yuxi City, China. In Water Fountains in the Worldscape; IWHA: Delft, The Netherlands, 2012; pp. 36-43.

66. Hynynen, A.J.; Juuti, P.S.; Katko, T.S. Water Fountains in the Cityscape; Hynynen, A.J., Juuti, P.S., Katko, T.S., Eds.; American Public Works Association: Kansas City, MO, USA, 2011.

67. Trafalgar Square. Available online: http://www.destination360.com/europe/uk/trafalgar-square.php (accessed on 10 April 2013).

68. Handbook of Water Kiosks from the Site of Federutility. Available online: http://www.federutil ity.it/openAttachment.aspx?IDFILE=04a49bf6-60a4-4467-b659-fb0d7f4c2038 (accessed on 22 April 2015). (In Italian)

69. Bond, T.; Roma, E.; Foxon, K.M.; Templeton, M.R.; Buckley, C.A. Ancient water and sanitation systems-Applicability for the contemporary urban developing world. Water Sci. Technol. 2013, 67, 935-941.

(C) 2015 by the authors; licensee MDPI, Basel, Switzerland. This article is an open access article distributed under the terms and conditions of the Creative Commons Attribution license (http://creativecommons.org/licenses/by/4.0/). 